\title{
NEW YORK CITY ENERGY-WATER INTEGRATED PLANNING: A PILOT STUDY
}

\author{
V. Bhatt, K.M. Crosson*, W. Horak, A. Reisman \\ *Presently at: \\ University of Dayton \\ Department of Civil and Environmental Engineering \\ 300 College Park, Dayton, OH 45469
}

\author{
Pilot Study Steering Committee \\ Chung Chan-New York City Department of Environmental Protection \\ Philip Heckler, P.E.-HDR, Inc. \\ Edward Linky, Esq.-U.S. Environmental Protection Agency, Region 2 \\ Joseph Madia, P.E.-Consolidated Edison, Inc. \\ Cynthia Rosenzweig, Ph.D.—Columbia University/NASA GISS \\ Amit Pramanik, Ph.D.-Water Environment Research Foundation \\ Boris Rukovets-Interstate Environmental Commission \\ Claudio Ternieden-Water Environment Research Foundation
}

December 16, 2008

\author{
Energy Sciences and Technology Department \\ Brookhaven National Laboratory \\ P.O. Box 5000 \\ Upton, NY 11973-5000 \\ www.bnl.gov
}

\begin{abstract}
Notice: This manuscript has been authored by employees of Brookhaven Science Associates, LLC under Contract No. DE-AC02-98CH10886 with the U.S. Department of Energy. The publisher by accepting the manuscript for publication acknowledges that the United States Government retains a non-exclusive, paid-up, irrevocable, world-wide license to publish or reproduce the published form of this manuscript, or allow others to do so, for United States Government purposes.
\end{abstract}


NEW YORK CITY ENERGY-WATER INTEGRATED PLANNING:

A PILOT STUDY

\title{
FINAL REPORT
}

$\underset{\text { NATIONAL LABORATORY }}{\text { BRDOKHONEN }}$

Brookhaven National Laboratory

Energy Sciences \& Technology Department

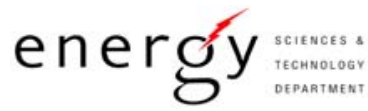

Energy, Environment and Economic Analysis Group

P.O. Box 5000, Upton, NY 11973

\author{
V. Bhatt, K.M. Crosson*, W. Horak, A. Reisman \\ *Presently at: \\ University of Dayton \\ Department of Civil and Environmental Engineering \\ 300 College Park, Dayton, OH 45469
}

\begin{abstract}
Pilot Study Steering Committee
Chung Chan-New York City Department of Environmental Protection

Philip Heckler, P.E.-HDR, Inc.
\end{abstract}

Edward Linky, Esq.-U.S. Environmental Protection Agency, Region 2 Joseph Madia, P.E.-Consolidated Edison, Inc.

Cynthia Rosenzweig, Ph.D.-Columbia University/NASA GISS

Amit Pramanik, Ph.D.-Water Environment Research Foundation

Boris Rukovets-Interstate Environmental Commission

Claudio Ternieden-Water Environment Research Foundation

July 2007

Revised: April 2008

Revised: October 17, 2008

Revised: November 13, 2008 


\section{Disclaimer}

This report provides illustrative-only modeling results to validate the concept, utility and applicability of an integrated energy-water decision-support tool for New York City. Steering Committee members provided comments and guidance for the project and report based on individual expertise, knowledge, and opinions. Thus, comments and information herein do not represent the views of their respective agencies, offices, foundations, companies, or commissions and should not be attributed to those entities. The project involved the preliminary development and application of an integrated energy-water decision support tool using referenced or illustrative data. The application of the model described in this report was the first step in an analysis of illustrative integrated energy-water cases. Published reports and articles were utilized as references, and media references were used only to highlight the views of the local area when relevant and necessary. 


\section{EXECUTIVE SUMMARY}

The New York City Energy-Water Integrated Planning Pilot Study is one of several projects funded by Sandia National Laboratories under the U.S. Department of Energy Energy-Water Nexus Program. These projects are intended to clarify some key issues and research needs identified during the Energy-Water Nexus Roadmapping activities.

The objectives of the New York City Pilot Project are twofold: to identify energy-water nexus issues in an established urban area in conjunction with a group of key stakeholders and to define and apply an integrated energy and water decision support tool, as proof-of-concept, to one or more of these issues.

During the course of this study, the Brookhaven National Laboratory project team worked very closely with members of a Pilot Project Steering Committee. The Steering Committee members brought a breadth of experience across the energy, water and climate disciplines, and all are well versed in the particular issues faced by an urban environment, and by New York City in particular.

The first task was to identify energy-water issues of importance to New York City. This exercise was followed by discussion of the qualities and capabilities that an ideal decision support tool should display to address these issues. The decision was made to start with an existing energy model, the New York City version of the MARKAL model, developed originally at BNL and now used globally by many groups for energy analysis. MARKAL has the virtue of being well-vetted, transparent, and capable of calculating "material" flows, such as water use by the energy system and energy requirements of water technology.

The Steering Committee members defined five scenarios of interest, representing a broad spectrum of New York City energy-water issues. Brookhaven National Laboratory researchers developed a model framework (Water-MARKAL) at the desired level of detail to address the scenarios, and then attempted to gather the New York City-specific information required to analyze the scenarios using WaterMARKAL.

This report describes the successes and challenges of defining and demonstrating the decision tool, Water-MARKAL. The issues that the stakeholders perceive for New York City are listed and the difficulties in gathering required information for Water-MARKAL to analyze these issues at the desired level of detail are described. 


\section{ACKNOWLEDGEMENTS}

Many people from diverse institutions contributed to this report. We especially thank the participants from the following institutions and teams:

- $\quad$ U.S. Department of Energy - In appreciation for seeing the need to examine energy-water nexus issues and providing initial funding support.

- Sandia National Laboratories - For thoughtful leadership of the Energy-Water Nexus National Laboratory Team.

- Energy-Water Nexus National Laboratory Team - In appreciation for membership on a team of dedicated individuals who provide their time and expertise in a collegial and collaborative manner.

- Pilot Study Steering Committee Members - A sincere thank you for the dedication, time, and expertise provided to the Pilot Study out of very busy schedules:

- Consolidated Edison, Inc. - Special thanks for procuring data for the modeling efforts.

- NYC Department of Environmental Protection - Sincere appreciation for assisting the BNL team with obtaining data for the modeling efforts.

- Earth Institute - NASA and Columbia: Appreciation for reminding us of the importance of climate issues in NYC.

- HDR, Inc. - Gratitude for hosting the initial and final pilot study Steering Committee meeting at the HDR, Inc. offices in Manhattan.

- Environmental Protection Agency Region-2 - Appreciation for providing resources for the prior development of NYC MARKAL and continued involvement. 


\section{TABLE OF CONTENTS}

\begin{tabular}{|c|c|}
\hline \multicolumn{2}{|r|}{ 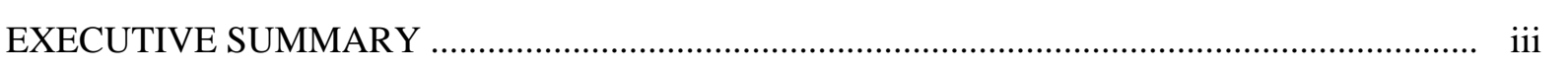 } \\
\hline \multicolumn{2}{|r|}{ 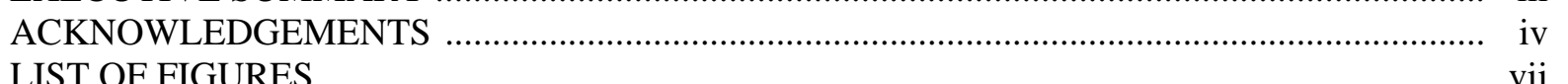 } \\
\hline \multicolumn{2}{|r|}{ 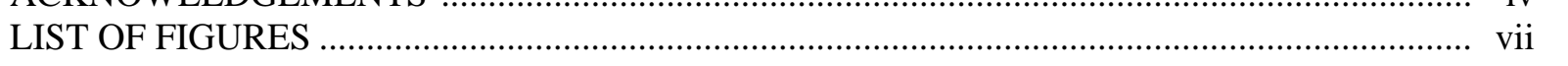 } \\
\hline \multicolumn{2}{|r|}{ LIST OF FIGURES } \\
\hline 1. & . \\
\hline 1.1 & Energy-Water Nexus .......................................... \\
\hline 1.1 .1 & 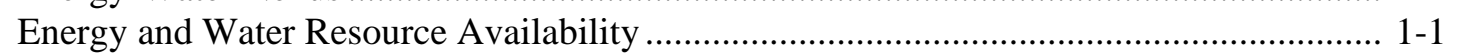 \\
\hline 1.1 .2 & 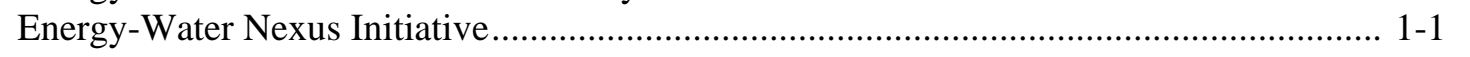 \\
\hline .2 & New York City Energy-Water Integra \\
\hline 1.2 .1 & Objectives of the BNL Integrated Energy-Water Pilot Study .......... \\
\hline 1.2 .2 & 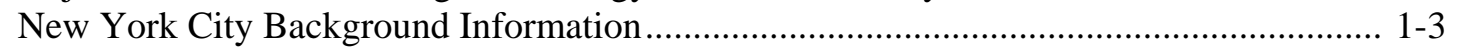 \\
\hline .2 .3 & 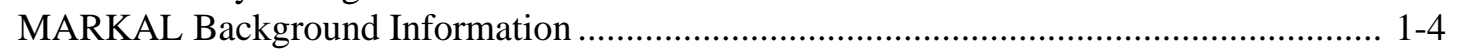 \\
\hline .2 .4 & New York City Energy-Water Nexus Pilot Study Approach ................................................ 1-4 \\
\hline . & NEW YORK CITY ENERGY-WATER CHALLENGES AND PLANNING ................... 2-1 \\
\hline 2.1 & 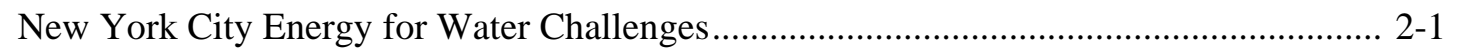 \\
\hline 2.1 .1 & $\begin{array}{l}\text { Increasing Energy Demands for the New York City Drinking Water } \\
\text { and Wastewater Systems }\end{array}$ \\
\hline .1 .2 & Water Co \\
\hline 2.1 .3 & ๔ City Wastewater Systems and Sewers................. \\
\hline 2.2 & for Fneroy Challenoes \\
\hline 2.2 .1 & Ensuring Future \\
\hline 2.2 .2 & Water Withdrawc \\
\hline 2.2 .3 & 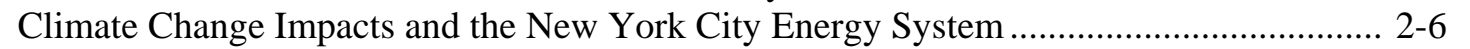 \\
\hline 2.3 & 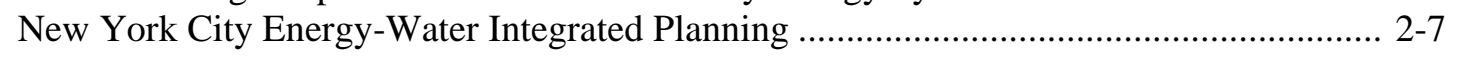 \\
\hline 3. & VC WA TED MADVAI • AN INTECDATED DECICION CIDDODT TOOI \\
\hline 3.1 & of an Energy-Water Integrated Decision Support Tool................ \\
\hline 3.1.1 & 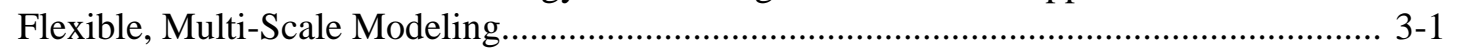 \\
\hline 3.1 .2 & Ability to \\
\hline 3.1.3 & lysis .......................... \\
\hline 3.1 .4 & 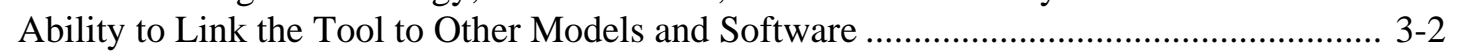 \\
\hline 3.1 .5 & 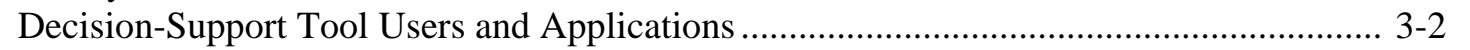 \\
\hline 3.2 & 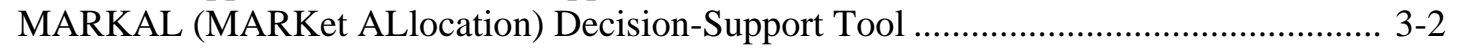 \\
\hline 3.2 .1 & NYC MARKAL ...... \\
\hline 3.2 .2 & NYC Water-MARKAL Development.... \\
\hline 3.3 & Application of NYC Water \\
\hline 3.3.1 & Initial Model Test \\
\hline 3.3 .2 & Scenario 1 - Water-Efficient Appliances: Energy and Water Use Impacts .......................... 3-8 \\
\hline 3.3 .3 & 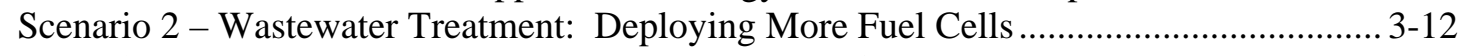 \\
\hline 3.3.4 & $\begin{array}{l}\text { Scenario } 3 \text { - New York City Water Supply: Impacts of Increased Energy Demand } \\
\text { for New Treatment }\end{array}$ \\
\hline & Sconario 1 - Now York City Stoam Conoration. Wator Sun \\
\hline & 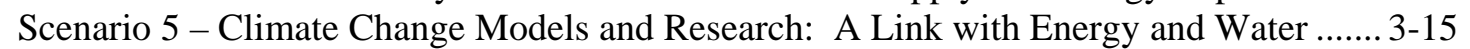 \\
\hline
\end{tabular}




\section{TABLE OF CONTENTS (Continued)}

Page

4. SUMMARY AND RECOMMENDATIONS …..................................................... 4-1

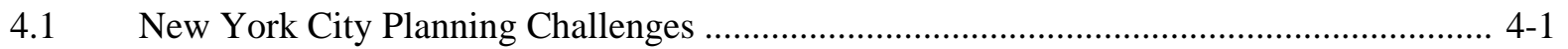

4.2 New York City Energy-Water Scenarios .................................................................... 4-1

4.3 Decision Tool Application - Proof-of-Concept ............................................................ 4-2

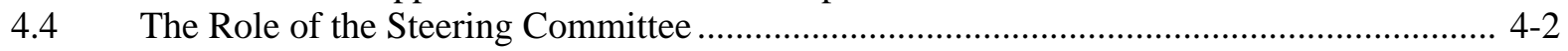

$4.5 \quad$ Future Work and Recommendations ......................................................................... 4-2

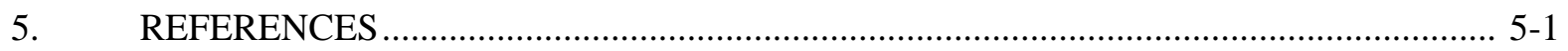

APPENDIX A: SUPPLEMENTAL INFORMATION AND SOURCES …................................ A-1

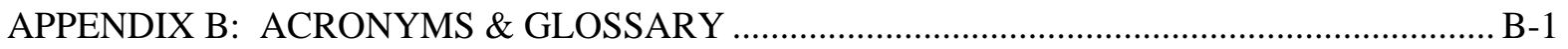

APPENDIX C: NEW YORK CITY: SUPPLEMENTAL WATER AND

ENERGY INFORMATION …........................................................................

APPENDIX D: DATA FOR NYC WATER-MARKAL MODELING SCENARIOS .................... D-1 


\section{LIST OF FIGURES}

Page

Figure 1 Projected Increase in NYC Energy Demands by 2030 without Intervention (NYC 2007) .......................................................................... 2-4

Figure $2 \quad$ Challenges Facing NYC Energy System........................................................... 2-8

Figure 3 Generalized Reference Energy-Water System in Water-MARKAL......................... 3-6

Figure 4 Total CO2 Emissions with Reductions in Electric Water Heating Demand .............. 3-7

Figure 5 Total System Cost Reductions with Decrease in Electric Water Heating Demand ... 3-8

Figure $6 \quad$ Water Savings with Efficient Washers........................................................... 3-10

Figure $7 \quad$ Electricity Savings with Efficient Washers..................................................... 3-10

Figure $8 \quad$ Emission Reductions with Efficient Washers ...................................................... 3-11

Figure $9 \quad$ Long-term Water Savings with Efficient Washers................................................... 3-11

Figure $10 \quad$ Wastewater Treatment Facility - Fuel Cell System Schematic ............................... 3-13

Figure 11 Projected Fuel Cell Capacity at NYC WWTFs .................................................. 3-13

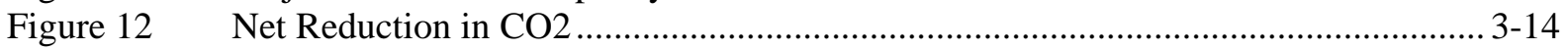

Figure 13 Net Reduction in Criteria Pollutants .............................................................. 3-14

\section{LIST OF TABLES}

Table $1 \quad$ New York City Energy-Water Integrated Planning Pilot Study - Steering Committee Members ....................................................................................... 1-5

Table 2 Typical Data Requirements for Integrated Water-MARKAL .................................. 3-4

Table 3 Components of the General Reference Energy-Water System .................................. 3-5

Table $4 \quad$ NYC Fuel Cells at Wastewater Treatment Facilities .................................................. 3-12 


\section{INTRODUCTION}

\subsection{Energy-Water Nexus}

Energy and water are two vital resources that are inextricably linked. Energy is used to deliver, clean, and utilize water resources and to convey and purify wastewater. Globally, $7 \%$ of total energy consumption is for water delivery, and $2-3 \%$ is consumed for water conveyance and treatment to serve urban populations and industry (ASE 2002). Water is used in the energy sector for extracting, producing, and processing energy resources (e.g., mining, biofuel crops, and refineries) and for power production (e.g., thermoelectric, hydropower, cogeneration). According to the United States Geological Survey (USGS 2004), 39\% of U.S. freshwater is withdrawn for thermoelectric power production. Based on estimates for water use in 2000, New York State was ranked sixth in the nation for total water withdrawals for thermoelectric power production (57\% of New York State freshwater withdrawals were for thermoelectric power generation).

\subsubsection{Energy and Water Resource Availability}

Fractions of the urban population are already underserved with regard to energy and water, so it is particularly important to manage energy and water resources sustainably in metropolitan areas. According to the United Nations (UN 2003), today one-half the world's populations lives in urban centers, compared to less than $15 \%$ in 1900. A lack of sustainable energy and water supplies in urban locales with large populations will significantly impact human health, food supply, environment, and economic growth.

\subsubsection{Energy-Water Nexus Initiative}

The United States Department of Energy (DOE), in recognition of the emerging energy-water issues facing many areas of the United States and the growing importance of sustaining energy-water resources for the future, initiated the Energy-Water Nexus (EWN) Program in 2005 to identify the science and technology needed to ensure energy and water security in the future (EWN 2007). Several DOE national laboratories, including Brookhaven National Laboratory (BNL), were assembled to participate in the EWN roadmap process. Through a series of workshops (regional, gaps analysis, science and technology) that brought together energy and water experts, energy-water regional issues and science and technology needs to address those issues were identified for the U.S.

One of the areas of research identified in the workshops was the need for integrated energy-water decision support tools that are capable of:

- assessing and comparing energy and water-related technologies;

- evaluating the impacts of policies and regulations;

- providing economic and environmental analysis; and

- incorporating details about the systems and factors that influence energy and water supply and demand (i.e., climate, water quality, land use, hydrology, etc.).

Prior to the roadmapping workshops, BNL jointly sponsored the New York Regional Energy-Water Workshop with Columbia University Earth Institute and the Electric Power Research Institute in April 2004 (BNL 2004). This workshop identified the energy and water issues facing southeastern New York and the planning, research, and development strategies necessary to ensure the region's future energy and water security. The primary energy and water issues in southeastern New York consisted of: 
- $\quad$ aging energy and water infrastructure;

- dense populations and land use limitations; and

- lack of integrated planning in the region.

As in the later DOE road-mapping workshops, the participants of the New York Regional Energy-Water Workshop cited the need for energy-water integrated planning decision-support tools. Specifically, the workshop participants proposed the development and application of a New York City integrated energy, environment, and economic model capable of tracking the water use requirements of energy end-use technologies and quantifying the energy use and efficiency of water treatment. The regional workshop also proposed research that involved analyzing the social consequences of various energy-water management scenarios using a decision-support tool.

Since the completion of the workshops, the DOE Energy-Water Nexus national laboratory team has continued energy-water activities, such as writing and finalizing reports, proposing and completing funded research projects, and presenting information at conferences and symposia. In February 2007, the Energy-Water Nexus Report to Congress was released, which discusses the relationship between energy and water resources and the associated water-related issues and challenges impacting energy production (DOE 2006). Also, forthcoming is the Energy-Water Nexus Roadmap Report that will discuss the leading science and technology research and development needed to address energy-water issues affecting the reliability and sustainability of future energy production.

To follow up on the groundwork described above, DOE sponsored five energy-water integrated planning pilot studies throughout the United States, to begin addressing some key issues identified during the Energy-Water Nexus Roadmapping activities. These studies have been undertaken by the DOE National Laboratories, with BNL leading the New York City Energy-Water Nexus Integrated Planning Pilot Study, the subject of this report.

\subsection{New York City Energy-Water Integrated Planning Pilot Study}

The New York City Pilot Study was formulated to identify energy-water nexus issues in an established urban area and to provide a hands-on test for the application and utility of an integrated energy and water decision support tool. New York City was chosen because it is a representative large urban center with an integral role in the international community that is facing population growth, with an aging energy and water infrastructure and projected increases in energy and water demands. In addition, a decision support tool (the MARKAL model) already exists for New York City as an energy analysis tool, has the capability to incorporate energy-related water information, and is a globally recognized energy decision support tool.

\subsubsection{Objectives of the BNL Integrated Energy-Water Pilot Study}

The specific objectives of the BNL New York City energy-water pilot study were to:

- identify New York City's leading energy-water issues;

- identify the challenges and strategies for integrated energy-water planning;

- identify integrated energy-water decision-support tool needs and capabilities (metrics, scalability, parameters, data needs, etc.);

- develop a preliminary version of an energy-water decision-support tool, based on MARKAL, as a proof-of-concept; 
- propose and analyze illustrative energy-water scenarios; and

- identify the activities and framework needed to achieve long-term integrated energy-water planning.

\subsubsection{New York City Background Information}

New York City is 321 square miles and water comprises about 160 square miles of the total area (NYCDCP 2007a). The New York City population is greater than 8 million and it is projected to increase by one million by 2030 (NYCDCP 2006; NYC 2007a). According to New York City Mayor Bloomberg, this anticipated population increase will significantly strain the city's aging energy and water infrastructure and the environment if sustainable planning is not completed. New York City has developed the PlaNYC2030 planning initiative to address these issues (NYC 2007a).

New York City's energy system is comprised of several power plants with different operators. Keyspan Energy, NRG Energy, Reliant Resources, New York Power Authority, and Con Edison, Inc. own or operate most of the in-city electricity generation sources. In 2003 , about $80 \%$ of the city's forecasted peak electricity needs of $11020 \mathrm{MW}$ were met by in-city generation plants, or about $8816 \mathrm{MW}$. The remaining electricity needed to serve the city is imported through transmission lines from upstate New York, northern New Jersey, and Long Island (NYC 2004). Although Consolidated Edison, Inc. operates some power plants, it is the company's mission to focus on transmitting and distributing electricity (NYC 2004; Con Edison 2007a).

The New York City water system is centuries old and is comprised of several reservoirs, lakes, aqueducts and tunnels. The two major parts of the water supply system are the Catskill-Delaware system and the Croton system, which are both located in upstate New York within 150 miles of New York City. Approximately 95-98\% of water supplied to New York City originates from the Catskill-Delaware system of reservoirs, lakes, and aqueducts. This water requires minimal treatment and is the most pristine of the water sources. The Croton water system is comprised of less pristine water that requires more treatment to remove particulates. Less than $1 \%$ of the water supplied to New York City comes from groundwater sources within a Queens aquifer (NYCDEP 2005a). New York City is supplied with 1.1-1.3 billion gallons of water per day (NYCDEP 2005a; NYC 2007a). Extensive efforts are underway to build new water tunnels to deliver water from the upstate reservoir systems to New York City. Currently, water is distributed from upstate reservoirs through two centuries-old water tunnels. Most of the water flows by gravity, so water distribution requires little or no energy.

The New York City wastewater system treats 1.4 billion gallons of water per day. The system is comprised of 14 wastewater treatment plants, 93 pumping stations, and over 494 permitted outfalls to discharge combined sewer overflows and storm water (NYCDEP 2006). At four wastewater treatment facilities, the New York Power Authority produces 1600 kilowatts of electricity from fuel cells, which use carbon dioxide and methane from anaerobic digesters (NYPA 2007). By utilizing carbon dioxide and methane for energy production, greenhouse gas emissions from wastewater treatment plants are lowered. Although the energy produced from fuel cells does not fulfill all the energy needs for wastewater treatment, it lowers energy costs for treatment. Additionally, wastewater treatment facilities already receive low-cost energy supplied by the New York Power Authority. Biosolids processing and disposal for New York City's wastewater treatment plants are another important energy-water linkage to consider. Some of these solids are sent to other states for disposal; making New York City's environmental footprint extensive. To process and transport these materials for disposal in other states, energy resources are utilized and vehicle emissions are released. 


\subsubsection{MARKAL Background Information}

The MARKAL (MARKet Allocation) modeling framework was chosen as the test methodology to analyze the integrated energy-water strategies. This model incorporates detailed information on energy resources, resource extraction and imports, energy generation and transmission, materials flow, and sector demands (i.e., residential, commercial, industrial, transportation) with detailed economic analysis and technology information. The model's time horizon is normally 30 to 50 years in 5-year increments, though it can be expanded further if desired. MARKAL's flexible modeling framework allows for multiscale (local, state, regional, national) development. MARKAL is data-intensive (Hamilton, et al. 1992, Loulou et al. 2004).

In 2005, the BNL Energy, Environment and Economic Analysis Group (EEEAG) developed the New York City version of MARKAL during a collaborative project with researchers at Stony Brook University, funded by the USEPA Region 2. A study of energy conservation and electricity load management strategies in office buildings in lower Manhattan was completed using the NEW YORK CITY MARKAL (Carroll et al. 2005). Since late 2005, the EEEAG has been developing another version of the model-NYC Water-MARKAL (EEEAG 2006). This version extends the application of the NYC MARKAL model and incorporates the New York City water system, wastewater system, water demands, water technologies, and costs into the model framework. Preliminary development of NYC WaterMARKAL included obtaining and inputting data about the drinking water and wastewater infrastructures. Generalized information was also obtained from New York City Department of Environmental Protection reports, environmental impact statements, New York City Water Board reports, and bond reports.

\subsubsection{New York City Energy-Water Nexus Pilot Study Approach}

A Steering Committee composed of diverse energy, water, wastewater, and environmental professionals was selected to assist with accomplishing the objectives of this pilot study. The Pilot Study Steering Committee consisted of the persons listed in Table 1 . They represent a diverse group of energy and water stakeholders from academia, industry, regulatory agencies, and research organizations that are knowledgeable and experienced with the complexities of New York City's energy and water systems.

The Steering Committee was involved in contributing to many of the major pilot study tasks. During a series of day-long meetings and two-hour conference calls, the committee:

- $\quad$ identified the energy-water issues for New York City;

- $\quad$ identified integrated planning needs and strategies;

- $\quad$ guided the development of the New York City Water-MARKAL integrated energy-water decision-support tool;

- $\quad$ assisted and guided BNL researchers in obtaining needed energy-water data and information for the study and decision-support tool development;

- $\quad$ selected key energy-water strategies to be analyzed using the New York City Water-MARKAL tool;

- $\quad$ suggested a strategy and framework for energy and water agencies and organizations at the local, state, and federal levels to complete integrated energy water planning; and

- $\quad$ reviewed and commented on the pilot study final report.

During meetings and conference calls, open discussions were encouraged and discussion sheets were provided to help keep meetings organized and timely. After identifying the New York City energy-water issues and integrated planning needs, challenges, and strategies, the Steering Committee members prioritized their comments. Based on Committee-identified priorities, issues, and needs, the BNL team 
developed a number of integrated planning strategies to examine using the NYC Water-MARKAL model. The final five model scenarios considered in the study were approved by the Steering Committee members.

Table 1. New York City energy-water integrated planning pilot study - steering committee members

\begin{tabular}{|l|l|l|}
\hline $\begin{array}{l}\text { Steering Committee } \\
\text { Member }\end{array}$ & Affiliation & Expertise \\
\hline Mr. Chung Chan & $\begin{array}{l}\text { Director of Air and Noise Unit, } \\
\text { Bureau of Environmental Planning, } \\
\text { NYCDEP }\end{array}$ & $\begin{array}{l}\text { Planning studies; air quality } \\
\text { analysis }\end{array}$ \\
\hline $\begin{array}{l}\text { Mr. Philip Heckler, } \\
\text { P.E. }\end{array}$ & $\begin{array}{l}\text { Vice President, HDR, Inc (consulting } \\
\text { firm) }\end{array}$ & $\begin{array}{l}\text { Risk analysis; wastewater } \\
\text { treatment; planning; Long Island } \\
\text { Sound study; }\end{array}$ \\
\hline $\begin{array}{l}\text { Mr. Edward Linky, } \\
\text { Esq. }\end{array}$ & $\begin{array}{l}\text { Senior Energy Advisor, US EPA } \\
\text { Region 2 }\end{array}$ & $\begin{array}{l}\text { Climate and energy; environmental } \\
\text { issues and law; energy efficiency; } \\
\text { and air quality }\end{array}$ \\
\hline Mr. Joseph Madia, P.E. & $\begin{array}{l}\text { Senior Engineer, Consolidated } \\
\text { Edison, Inc. }\end{array}$ & $\begin{array}{l}\text { Planning the gas distribution } \\
\text { system; model gas systems; } \\
\text { forecasting electric demand; power } \\
\text { plant engineering work }\end{array}$ \\
\hline $\begin{array}{l}\text { Cynthia Rosenzweig, } \\
\text { Ph.D. }\end{array}$ & $\begin{array}{l}\text { Senior Research Scientist, Center for } \\
\text { Climate Research, Columbia } \\
\text { University } \\
\text { NASA Goddard Institute for Space } \\
\text { Studies }\end{array}$ & $\begin{array}{l}\text { Climate change; author of Metro } \\
\text { East Coast study; climate group and } \\
\text { committee with NYC DEP; urban } \\
\text { modeling consortium; 2004 New } \\
\text { York Regional Energy-Water } \\
\text { Nexus Workshop }\end{array}$ \\
\hline $\begin{array}{l}\text { Mr. Boris Rukovets, } \\
\text { P.E. }\end{array}$ & $\begin{array}{l}\text { Senior Program Director for } \\
\text { Wastewater Treatment \& Reuse, } \\
\text { Water Environment Research } \\
\text { Foundation }\end{array}$ & $\begin{array}{l}\text { Assistant Executive Director \& } \\
\text { Essistant Chief Engineer, Interstate } \\
\text { Environmental } \\
\text { energy use and issues for } \\
\text { wastewater treatment }\end{array}$ \\
\hline $\begin{array}{l}\text { Assistant Director of Research, Water } \\
\text { Environment Research Foundation }\end{array}$ & $\begin{array}{l}\text { Modeling; water resources } \\
\text { Riverkeepers; environmental } \\
\text { permits for wastewater treatment } \\
\text { plants }\end{array}$ \\
\hline
\end{tabular}




\section{NEW YORK CITY ENERGY-WATER CHALLENGES AND PLANNING}

The Steering Committee members discussed the energy and water issues facing New York City over the next 20-25 years. They discussed New York City energy and water topics during open discussions in a day-long meeting held at the HDR, Inc. offices in Manhattan. Prior to the meeting, a matrix with a preliminary list of general energy and water topics was provided to the Steering Committee to foster ideas and discussion. This matrix was also used to capture comments from Steering Committee members. A BNL researcher facilitated the discussion and recorded comments using a large flipchart, while two other BNL researchers also recorded information via handwritten and electronic notes.

\subsection{New York City Energy for Water Challenges}

Several issues emerged from the discussions, but the Steering Committee members concluded that the leading concerns with regard to energy needs for New York City water and wastewater systems to address through integrated planning are:

1. handling the increasing energy demands for the reliable operation of New York City drinking water and wastewater systems;

2. enforcing and assessing the total benefits (e.g., water and energy savings) of New York City water conservation initiatives; and

3. assessing climate change impacts (e.g., sea level rise, increases in storm intensity, and flooding) on New York City wastewater treatment plants and the sewer system.

\subsubsection{Increasing Energy Demands for the New York City Drinking Water and Wastewater Systems}

The Steering Committee members identified rising energy demands for the New York City water supply system as a leading New York City energy-for-water challenge. New York City’s water supply system is one of the nations oldest and supplies at least 1.1 billion gallons per day (BGD) of very high quality water to New York City residents and visitors (NYCDEP 2005a; NYC 2007a). Continuing to reliably provide quality water to New York City will require protecting upstate water supply reservoirs, increasing redundancy in conveyance systems, installing new treatment technologies, and upgrading conveyance infrastructures (i.e., aqueducts, tunnels, water mains) (NYC 2007a). Several projects are planned by the New York City Department of Environmental Protection (NYCDEP) to address these needs; however, some projects will require the supply of additional energy.

For instance, the NYCDEP plans to construct an ultraviolet (UV) treatment system to disinfect up to 2020 MGD of Catskill and Delaware system water by 2012. When completed, this UV plant will be the largest in the world (NYC 2007a; Potorti 2007). Although the energy requirements for UV treatment varies based on water quality conditions, UV dose, and UV lamp technology, typical energy use for UV treatment can range from 77-160 kWh/MG (SBW 2006). The NYCDEP estimates that $6.3 \mathrm{MW}$ of electricity is required to operate the plant at full capacity, and $4.45 \mathrm{MW}$ would be necessary to treat the average daily flow of 1310 MGD. Backup power during emergencies would be supplied by four diesel generators. Natural gas from Con Edison, Inc. will be used to heat the UV facility, except in the case of extremely cold weather, when fuel oil will be utilized (NYCDEP 2004a).

Another water treatment project, the $\$ 1$ billion Croton filtration plant, is also expected to be complete by 2012 (NYCMWFA 2006). This will be New York City's first filtration plant and will be capable of 
treating 290 MGD of water from the Croton water supply system (NYCDEP 2004b; NYC 2007a). This filtration plant is necessary to comply with the federal Safe Drinking Water Act regulations (NYCDEP 2004b; NYC 2007a). Filtration is an energy-intensive treatment process that requires the operation of pumps, fans, and other energy-consuming equipment. It is estimated that $32.3 \mathrm{MW}$ of power will be needed to treat 290 MGD of Croton water. To treat the daily average flow of 144 MGD, about 22 MW of electricity will be required. Emergency power would be supplied from two diesel generators (NYCDEP 2004b).

In April 2007, the US EPA granted the NYC DEP a draft 10-year Filtration Avoidance Determination (FAD) (NYC 2007a) allowing New York City to avoid building an $\$ 8$ billion water filtration plant to treat the Catskill and Delaware system water, which would raise water rates and require additional energy resources. Although New York City is one of five large U.S. cities with an FAD, the EPA might require water filtration if water quality diminishes in the Catskill and Delaware systems in the future. The New York City Energy-Water Pilot Study Steering Committee estimated that filtering Catskill and Delaware system water could require an additional 200-300 MW of energy. Thus, the largest perceived risk to the New York City water system is diminished water quality created by the development of communities surrounding the water supply watersheds, an issue extensively reported in the New York City press (see Appendix A). Preserving the water quality in upstate water supply watersheds through watershed protection activities is important to protect water quality and to prevent the need for additional energyintensive water treatment operations.

Protecting and enhancing water quality in the bays, sounds, and rivers surrounding New York City is also a priority. The nitrogen level in New York City wastewater treatment plant effluents is regulated to protect the Long Island Sound and Jamaica Bay (NYC 2007a). According to the Pilot Study Steering Committee, the NYCDEP is investing in biological nutrient removal technology to mitigate water quality impacts to these water bodies. Since nutrient removal technology can be costly and energy intensive, NYCDEP is assessing the potential of emerging technologies such as SHARON, ARP, and Biolysis "O" (NYC 2007a). Increased investment in nutrient removal technology will lead to increased wastewater treatment energy demand.

Although nutrient removal and other wastewater treatment processes consume energy, New York City is capitalizing on technology available to produce energy from wastewater. About $60 \%$ of digester gas from New York City wastewater treatment facilities produces energy using fuel cells (NYC 2007a; NYPA 2007). According to the Steering Committee, the fuel cells do not produce enough energy to completely operate the plants or provide supplemental energy to New York City’s energy grid.

Ensuring a reliable energy infrastructure capable of meeting the increased demands for the New York City water system and its new projects is a key challenge. According to Steering Committee members, Consolidated Edison, Inc. has already modified its peak load planning to account for increasing energy demands for NYCDEP's water and wastewater operations and projects. Con Edison, Inc. is also investing in the energy infrastructure to meet these demands (Con Edison 2007b).

\subsubsection{Water Conservation Initiatives}

Although New York City is not facing immediate water scarcity concerns, droughts have occurred. Also, reducing water demand is a useful tactic to avoid potential water shortfalls when critical aqueducts (e.g., Delaware River) are shutdown and upgraded (NYC 2007a). The New York City Department of Environmental Protection has been successful in implementing incentive-based water conservation initiatives such as water metering and low flow toilets. However, participation in conservation programs is merely encouraged and not enforced, and most participation is derived from the consumer's interest in saving money. 
Since many New York City residents live in multi-family dwellings, an incentive program for efficient washing machines, toilets, and urinals is slated to begin in 2008 to curtail water use (NYC 2007a). The expected water savings from this program is about $60 \mathrm{MGD}$ or $5 \%$ of current water use. However, there are additional benefits, such as energy savings, that can be achieved through water conservation which are often not considered or assessed when promoting water conservation programs. Reducing the amount of water used also reduces the amount of water requiring treatment in New York City wastewater treatment plants, which leads to energy conservation. Since wastewater treatment plants emit greenhouse gases it would be useful to quantify how water conservation initiatives lead to decreases in emissions.

\subsubsection{Climate Change Impacts on New York City Wastewater Systems and Sewers}

Recent work has shown that managing risk by adapting long-lived infrastructure to the impacts of climate change must become a regular part of planning for water supply, sewer, wastewater treatment, and other urban infrastructure during this century (Rosenzweig et al., 2007). The Pilot Study Steering Committee cited the impacts of sea level rise and increasing storm intensity on the New York City gravity-fed wastewater and sewer systems and the flooding of low-lying New York City wastewater treatment plants as primary concerns associated with climate change. According to the Intergovernmental Panel on Climate Change (IPCC), U.S. scientists and U.S. military experts, global warming will cause water shortages, flooding, and more intense storms in the U.S. (IPCC 2007a). In particular, sea level rise leading to storm surges will be a key threat to East coast metropolitan areas such as New York City (Rosenzweig and Solecki 2001). Although New York City wastewater treatment plants are designed to treat twice their dry-weather flow, approximately $80 \%$ of the city functions on a combined sewer system (Protopapas 1999) and only about 60\% of rainfall is collected and treated (NYCDEP 2001). Combined

sewer overflows (CSOs), which may increase with climate change already, are a significant source of environmental pollution in New York, and a growing concern in Lower Manhattan. Upgrades to wastewater infrastructure with tide gates have been useful for preventing flooding of wastewater treatment plants resulting from sea level rise (NYCDEP 2005b), and there is interest in building more tide gates both for storm surge protection and pollution control in the East River (Van Lenten 2005).

\subsection{New York City Water for Energy Challenges}

Concerns about water supply for energy generation are key issues in many U.S. regions, but this is not a pivotal concern for New York City. The energy production facilities providing energy to New York City are thermoelectric power plants that utilize once-through cooling technology. These energy generation facilities do not rely on the same water sources used to provide drinking water for New York City residents and visitors. The Pilot Study Steering Committee identified the following as the leading challenges for the New York City energy system:

1. ensuring future energy security and supply;

2. water withdrawals and needs for steam production; and

3. climate change impacts related to energy production (e.g., efficiency of energy generation, energy demands, emissions from power production).

\subsubsection{Ensuring Future New York City Energy Security and Supply}

Despite the fact that New York City has the most reliable energy grid in the U.S. within the next 4-8 years, an energy shortfall is expected for New York City (NYC 2007a). Aging infrastructure coupled with growing energy demands spurred by development and a projected population increase are driving the strain on the NYC energy system. 
There have been several estimates of the need for future electricity generation capacity additions by different agencies under different time assumptions. The New York City Energy Policy Task Force's 2004 NYC Electricity Roadmap Report projected an additional need of 2600 MW by 2008 (NYC 2004). The New York Independent System Operator's (NYISO) second Reliability Needs Assessment report stated that by 2011 New York City and the Lower Hudson Valley region will require an additional 1250 MW of energy (NYISO 2007a); by 2016, a total of 3105 MW of additional resource additions, including the new capacity, transmission additions and demand reductions will be needed. Most recently, the Mayor's Office of Long-Term Planning and Sustainability projected that New York City will need an additional 2000-3000 MW of generation capacity by 2015 (NYC 2007a). Articles describing the potential energy strain and their implications on the financial sector are highlighted in local New York City newspapers (see Appendix A).

If reductions in electricity and energy demand are not achieved by 2030, the city's peak electricity demand, electricity consumption, and heating fuel consumption will increase as shown in Figure 1 (NYC2007a).

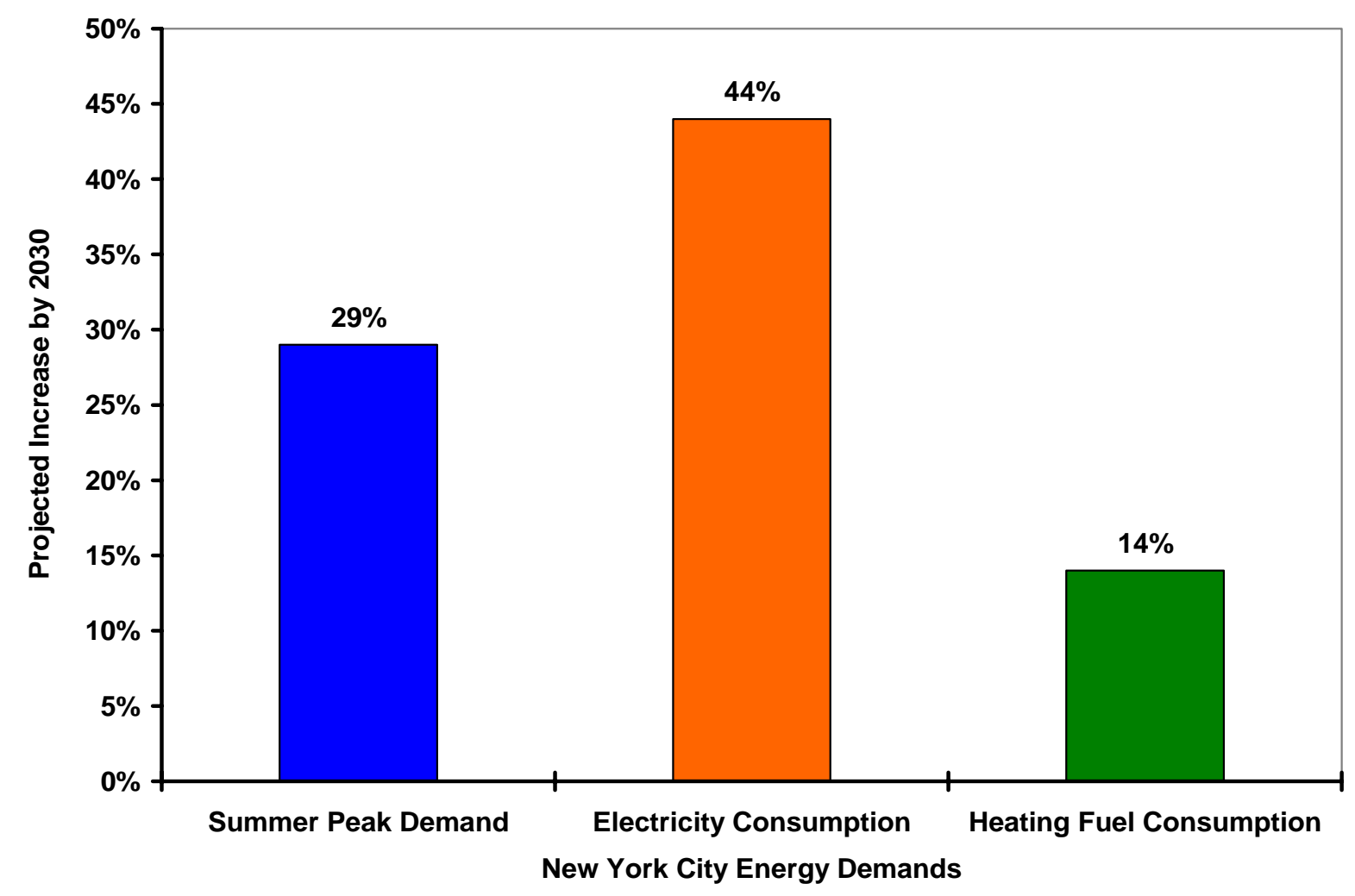

Figure 1. Projected increase in NYC energy demands by 2030 without intervention (NYC 2007) (Sources: Keyspan, Con Edison, Inc., Mayor’s Office of Long-Term Planning and Sustainability)

Upgrading aging infrastructure is critical to addressing New York City’s energy problems. Buildings consume over two-thirds of energy used in New York City, as compared to less than one-third nationally (NYC 2007a), and older buildings that are not properly maintained contribute to inefficient energy use. A bill has been proposed that would require owners to bring older buildings up to code (Appendix A). The existing energy generation facilities serving New York City are over 30 years old, and they are not using the most efficient or clean technologies available. The Office of Long-Term Planning and Sustainability projected that by 2012, these facilities will not provide enough energy to meet the city’sdemands (NYC 2007a). Additionally, some power plants are expected to be retired by 2012. 
NYISO forecasted the retirement of the Charles Poletti plant in 2009, and several other power plants from 2007-2009 (NYISO 2007a). If new power plants are built or older facilities are upgraded, they might be required to install cooling towers to comply with the Clean Water Act's 316a and 316b rules that limit thermal pollution and water withdrawals by power plants (NETL 2006). The use of cooling towers will lead to lower water withdrawals, but increase water consumption Moreover, building new power plants is a costly venture in New York City. The cost of building new power plants in New York City is about "three times the national average" due to siting issues (e.g., land availability), construction prices, and large financing requirements (NYC 2007a).

New York City's underground energy delivery infrastructure is also aging. The delivery infrastructure's technology and intricate design make it difficult to quickly repair or manage large power outages. This was evidenced in July 2006, when a large power disruption caused by failing electric cables occurred in Queens that affected many Queens businesses, residents, and visitors for days or weeks (NYC 2007a). Since then, Consolidated Edison, Inc., New York City's primary energy delivery company, has invested heavily in its electricity network throughout its entire service area (Westchester and the City of New York). Con Edison, Inc. has installed miles of underground and aerial cable and high voltage transmission cable, new transformers at substations, began construction of new substations, and invested over a billion dollars for electric transmission and distribution (Con Edison 2007a).

Energy transmission to the New York City area is another option for meeting future energy demands. The NYISO regularly engages in Resource Adequacy Planning that is intended to ensure that an adequate combination of installed generation capacity and transmission capability is available to meet the needs of New York residents (NYISO 2007b). Recently, New York Regional Interconnect has proposed a 1200 MW power line that would be built throughout several upstate communities. However, energy transmission from upstate New York to New York City presents land use, environmental, and political concerns for upstate residents and officials, thus, as been reported in the press (see Appendix A), resistance to this proposal is strong New York Regional Interconnect is also researching alternate routes for the power lines that would follow NY state thruways or the existing power line route. If opposition to building additional transmission capacity for New York City continues, this might not prove viable for meeting New York City's future energy demands.

Lowering energy usage through energy efficiency will also be necessary to meet future energy requirements. Despite efforts to curtail energy demands during a summer heat wave in August 2006, the reductions in energy use were not enough to prevent a strain on the grid and a record was set for electricity demand (NYC 2007a). To avoid a blackout, it was necessary to utilize old, inefficient power plants and businesses resorted to using diesel generators. These actions released air pollutants, and resulted in a 500\% rise in NYC electricity prices on the day of record electricity demand (NYC 2007a).

Consolidated Edison, Inc. is taking an active role in reducing energy demands by establishing and/or participating in several energy efficiency programs and activities (Con Edison 2007a; Con Edison 2007c). For instance, Con Edison, Inc. is sponsoring the "Operation Kill-A-Watt" program which will provide $\$ 10$ million for energy efficient upgrades for buildings (Con Edison 2007c). Columbia University is participating in an energy conservation program, Operation Save New York, which compensates the University for saving energy (Columbia 2007, ECS 2007). The Office of Long-Term Planning and Sustainability has also proposed the establishment of an official energy efficiency authority for NYC to coordinate city-wide efforts for efficient utilization of energy resources. Peak load management and real time pricing are also proposed initiatives (NYC 2007a). 


\subsubsection{Water Withdrawals and Needs for New York City Steam Production}

Steam is used in New York City to heat, cool, and supply hot water to offices, multi-family dwellings, and hospitals. Consolidated Edison, Inc. operates the New York City steam system, which is the largest in the world (Con Edison 2007d). The peak demand for steam occurs during the winter, and it ranges from 8 to 12 million lbs steam/hour (Con Edison 2007a). Steam is produced by Con Edison, Inc.'s steam generation plants and steam-electric plants, and about 20\% is purchased (Con Edison 2007a). Water used to produce steam is withdrawn from the NYCDEP's Croton water system, which is also used to supply drinking water to New York City. The steam production process utilizes $100 \%$ withdrawn water, and condensate from utilized steam enters the NYCDEP sewer system for treatment at wastewater treatment plants. Thus, water is consistently withdrawn from the Croton water system to provide steam. Con Edison, Inc. also treats this water to remove particulates and other impurities prior to steam production. According to the Pilot Study Steering Committee, about 12 MGD of water from the Croton system is used to produce steam. In the winter, 20 MGD of water is withdrawn to satisfy peak demands. The NYCDEP is exploring alternative methods of reusing the condensate rather than treating it at wastewater treatment plants, which consumes energy and produces emissions during the treatment process. It would be useful to determine the costs and benefits of utilizing more pristine water sources for steam production to reduce the cost of treating the water and/or finding alternate water sources for steam generation. Should water resources become strained in the future due to droughts or disruptions in New York City primary water supply sources (Delaware and Catskill water supplies), this could impact the amount of water allocated for steam production. However, utilizing another water source for steam production such as the East River would require significant changes to the steam infrastructure and investments from Con Edison, Inc.

\subsubsection{Climate Change Impacts and the New York City Energy System}

The Steering Committee identified the impacts of climate change on the New York City energy system as a critical issue to address. Climate change is expected to have both direct and indirect effects on the energy system. Direct effects include an increased threat of flooding for vulnerable infrastructure; indirect effects include increased stress on the power sector through increased electricity demand for cooling, particularly at peak times. The Metro East Coast Assessment projected that daily peak load would increase from $7-12 \%$ in the 2020 s, $8-15 \%$ in the 2050 s, and $11-17 \%$ in the 2080 s (Hill and Goldberg 2001).

New York City is particularly vulnerable to climate impacts, such as sea level rise and coastal flooding (Rosenzweig 2001; NYCDEP 2005a). The Office of Long-Term Planning and Sustainability stated that rising water levels in Lower Manhattan have already increased the likelihood of the 100-year flood occurring every 80 years instead of 100 years (NYC 2007a). Flooding could disrupt important New York City energy infrastructure such as power lines and the natural gas system. Shutting down the New York City natural gas system due to flooding would be quite difficult, and it would take days or weeks to safely resume operations. Repairing New York City’s complex electric grid would also take considerable time.

Scientists also predict that global temperatures will rise by $1.8-4.0^{\circ} \mathrm{C}$ (best estimates) by the 2090s if efforts to curtail global warming are not implemented (IPCC 2007b). Recent estimates for the New York City region in the 2080s are for $2.4-4.1^{\circ} \mathrm{C}$ (This estimate is the mean of five global climate models for greenhouse gas emission scenarios representing low, medium, and high emissions) (Rosenzweig, personal communication). In the summer of 2006, high temperatures in New York City produced heat waves leading to record peak electricity demand. Very high temperatures reduce the efficiency of energy production at a time when energy needs for cooling are increasing. 
To meet peak demand, inefficient older power plants in New York City are used to augment the energy supply, resulting in release of more greenhouse gases that contribute to global warming. In 2007, the Mayor's Office of Long-Term Planning and Sustainability released a greenhouse gas inventory report for New York City showing that the city emits about 1 percent of the U.S. greenhouse gas emissions (NYC 2007b). Installing newer cleaner power plant technology, distributed generation, combined heat and power, and renewable energy technologies in the city for energy generation are prudent ways to reduce greenhouse gas emissions while meeting energy demand.

\subsection{New York City Energy-Water Integrated Planning}

Several of the New York City energy and water issues identified by the Steering Committee can be addressed through long-term integrated planning. Planning for future energy and water needs has traditionally been conducted separately in the United States. Energy and water offices, agencies, and organizations will need to develop and implement strategies for collaboration to successfully undertake and complete integrated planning. Prior to initiating an energy-water planning effort, it would be useful to determine the planning timeframe and priorities of the groups involved.

The New York City Department of City Planning (NYCDCP) provides technical and data planning resources (populations, city maps, etc.); prepares strategic plans and policies; and oversees land use, environmental review, and permits for the physical and socioeconomic development of the city (NYCDCP 2007b). Other city offices, such as the New York City Department of Environmental Protection (NYCDEP) can obtain information and assistance from the Department of City Planning about new development and population estimates to prepare their own strategic plans.

The NYCDEP's Bureau of Environmental Planning and Assessment conducts environmental reviews for NYCDEP and other city agencies; completes strategic planning for NYCDEP to assist with modeling, research, and forecasting; and assists NYCDEP with planning for future growth and development in the city. According to the Steering Committee members, 10-year planning for New York City's water and wastewater sectors is typical. Budgets for the water and wastewater systems are also developed and allocated based on a 10-year cycle. For NYCDEP projects and planning strategies, an emphasis is placed on meeting water quality needs through reliable, effective designs and equipment. NYCDEP must create designs and plans that will allow the Agency to meet consent decrees and mandatory milestones with regard to water quality. Although energy plays a secondary role in design and planning, NYCDEP is conducting energy studies and has implemented energy efficiency in its operations (e.g., wastewater treatment fuel cells).

Several companies, offices, and organizations contribute to the managing and planning of the New York City energy system (NYC 2007a). Con Edison, Inc. is the energy delivery company serving the city, and the company completes planning and budgeting activities to ensure sustainable energy delivery. Various companies are responsible for the facilities that generate energy for the city (e.g., New York Power Authority (NYPA), Keyspan Energy, NRG Energy, Reliant Resources, Con Edison, Inc.). The energy issues facing New York City are related to generation, delivery, and demands. Solutions to these challenges will require integrated planning (see Figure 2 below).

However, as the PlaNYC: A Greener, Greater New York report stated, no planning board exists that can provide comprehensive, integrated planning for the entire energy system-generation, delivery, and demand management. Thus, the Office of Sustainability and Long-Term Planning recommended the establishment of a New York City Energy Planning Board to oversee the future planning of energy system (NYC 2007a). 


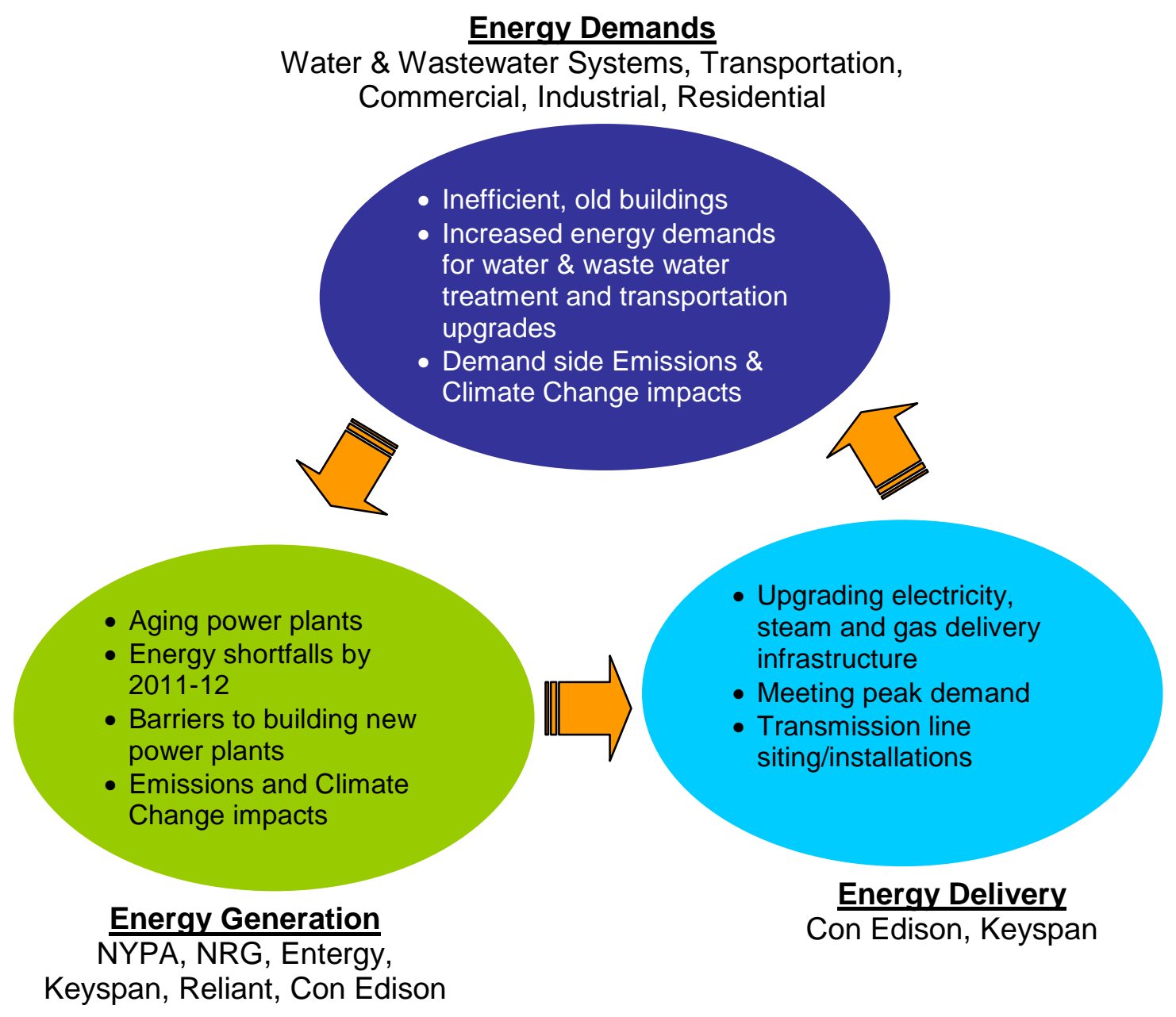

Figure 2. Challenges facing the NYC energy system

Long-term integrated planning between New York City's water/wastewater and energy sectors does not typically occur. Coordination between NYCDEP and Con Edison, Inc. usually involves specific projects, where Con Edison, Inc. reacts to NYCDEP's demand forecasts and energy requests. This type of interaction impacts Con Edison, Inc.'s overall energy planning and budget. To address such New York City energy-water issues, the Pilot Study Steering Committee endorsed the usefulness of long-term, macro-scale planning for the New York City energy and water systems. Additionally, the establishment or designation of an agency or office to develop and manage the energy and water strategic planning was suggested. Currently established offices or groups, such as New York City's Economic Development Corporation or Office of Long-Term Planning and Sustainability, could serve this role. The Energy Policy Task Force has already evaluated and set goals for the New York City energy system in the New York City Electricity Roadmap Report (NYC 2004). The task force also continues to provide updates on the milestones outlined in the report. The Office of Long-Term Planning and Sustainability produced the Inventory of New York City Greenhouse Gas Emissions and PlaNYC: A Greener, Greater New York reports (NYC 2007a; NYC 2007b). This recently-formed office clearly mapped out New York City's future energy and water concerns. Both entities have worked extensively with other energy and water agencies, groups, and companies responsible for New York City's energy and water systems. 


\section{NYC WATER-MARKAL: AN INTEGRATED DECISION-SUPPORT TOOL}

Decision-support tools can facilitate improved integrated energy-water planning for New York City. The PlaNYC: A Greener, Greater New York report (NYC 2007a) outlined several initiatives for meeting the challenges facing New York City's energy and water systems in the future. The proposed initiatives will impact on and benefit New York City energy and water systems, but the report does not highlight inherent links between energy and water. The costs and benefits of these initiatives and specific projects could be analyzed with a decision-support tool capable of long-term analysis for both energy and water to highlight the cross-cutting effects on energy and water systems.

\subsection{Desired Characteristics of an Energy-Water Integrated Decision Support Tool}

The Pilot Study Steering Committee expressed interest in an energy-water decision-support tool with the following capabilities:

1. flexible, multi-scale modeling (e.g. city, watershed, state, and regional);

2. ability to securely manage and update data and alter data metrics;

3. technology comparison and process comparison (e.g., life cycle costs, energy and water use, materials consumption and production);

4. short and long-term energy, environmental, and economic analysis (5-50 years); and

5. ability to link the tool to other models and software.

\subsubsection{Flexible, Multi-Scale Modeling}

A flexible model that can be applied on various scales is needed meet the needs of multiple users. Since water issues and sources vary spatially, a model must account for differences in water supply and watershed character at the watershed level.

\subsubsection{Ability to Securely Manage and Update Data and Alter Data Metrics}

Data handling methods are also a key component of decision-support tools. In some instances, the level of detail needed for energy and water modeling requires data that are not available in published reports and databases. In those situations, it is necessary to contact specific agencies, offices, and companies to obtain proprietary data and legal approval for data use. Thus an effective method for securely managing and updating data is essential. Additionally, the flexibility to vary data metrics to accommodate different data sources and provide the most suitable analysis is also a useful model attribute. Energy and water sectors do not always speak the same "language," so it might be necessary to use different metrics to describe the material usage of energy and water technologies.

\subsubsection{Technology and Process Comparison}

Comparing energy and water technologies to elucidate benefits and costs of various strategies in energy and water systems is an essential feature for decision-support tools used in energy-water integrated planning. The American Water Works Association Research Foundation (AWWARF) and the California Energy Commission (CEC) have been active in defining research and tools needed to examine technology requirements and energy efficiency in water use and treatment. In particular, AWWARF and CEC's Water and Wastewater Industry Energy Efficiency: A Research Roadmap report stated that decision- 
support tools are needed to compare and evaluate the following: advanced treatment technologies and processes; energy generation and recovery methods; energy optimization strategies; desalination processes; disinfection methods; and energy use by specific water and wastewater processes (AWWARF and CEC 2004).

\subsubsection{Short and Long-Term Energy, Environmental, and Economic Analysis}

Another useful model feature is the ability to evaluate and analyze strategies on short and long-term time horizons. The AWWARF and CEC Research Roadmap report mentioned above highlighted the need for better forecasting tools to obtain more accurate water demand information to assess the needs for pumping and conveyance of water. The New York City Department of Environmental Protection is currently planning a 10-year budget plan; thus, a tool capable of long-term planning could compare many of the initiatives suggested for implementation to solve energy and water issues that will face New York City by 2030. Long-term planning can also begin to reveal the potential effects of climate change and the impacts of new regulations and infrastructure on energy and water systems.

\subsubsection{Ability to Link the Tool to Other Models and Software}

The ability to link the model to other decision-support tools (e.g., climate change models, water quality models) and data management programs (geographic information systems) would also appeal to many users. It is unlikely that a single decision support tool that provides an integrated overview of energywater interactions will be capable of detailed analyses of energy and water systems; consequently, the ability to link the tool to other software will allow users to expand their modeling capabilities and solve more complex issues.

\subsubsection{Decision-Support Tool Users and Applications}

The Steering Committee noted that a decision-support tool with the aforementioned attributes would be useful to many energy and water entities and help promote integrated planning across diverse stakeholders. Local or state governments and regional planning associations could use the tool to develop and/or evaluate energy and water policies or planning strategies. University researchers could apply the tool to compare new water and energy processes and technologies or assess climate change emissions. Companies and governments would find it useful for making decisions that affect economic development and construction of new facilities.

\subsection{MARKAL (MARKet ALlocation) Decision-Support Tool}

There are several decision-support tools capable of either integrated energy systems analysis or watershed/water quality assessments and management. Rather than develop a new tool for integrated energy-water systems analysis, BNL with concurrence from the Steering Committee, chose to extend the capabilities of an existing decision-support tool (Hamilton et al. 1992, Loulou et al. 2004). Our team found it more prudent for this initial study to modify an energy systems model, rather than a watershed/water quality model, because many of the available energy systems tools are widely used, capable of multi-scale analysis, upgraded often, and energy data are more readily available than water data. Thus, BNL/EEEAG researchers suggested the energy systems model, MARKAL (MARKet ALlocation) to develop an integrated, comprehensive energy-water decision-support tool that models water and wastewater flows, infrastructure, technologies, and water demands and the associated energy use and economic considerations. 
MARKAL uses a framework, the reference energy system (RES), to describe energy flows from supply to demand, including: energy resources and extraction; refineries and processing: power production and transmission: demands and end-use technologies. The MARKAL model's output consists of a least-cost energy system subject to specified constraints and policies, and it can forecast over a user-defined time horizon. The model's flexible framework allows it to be developed for systems analysis at global, national, regional, and local scales.

\subsubsection{NYC MARKAL}

In 2005, our research team developed the New York City version of MARKAL (NYC MARKAL) (Carroll et al. 2005). This project was a collaborative project with researchers at Stony Brook University and was funded by the USEPA Region 2. With this model, we completed a study of energy conservation and electricity load management strategies in office buildings in lower Manhattan. The time horizon for this version of the model is 2030 .

BNL's application of and familiarity with MARKAL and development of MARKAL-based tools is also demonstrated by the following projects, making MARKAL a logical choice for a small pilot project:

1. multi-regional analysis in GHG mitigation and trade for US EPA;

2. strategic planning in technology R\&D for DOE's Offices of Energy Efficiency and Renewable Energy (EERE) and Nuclear Energy (NE);

3. coordination of Central American Cooperation on regional energy issues;

4. data collection and integration from multiple agencies and model development and calibration for the generation of the DOE Energy Information Administration's International Energy Outlook; and

5. support of Taiwan Environmental Protection Agency’s (TEPA) national energy planning.

\subsubsection{NYC Water-MARKAL Development}

When developing a new variant of the MARKAL model, it is important to clearly understand its intended application. Thus, it is necessary to obtain accurate knowledge about the area for which the model will be developed, the energy-water concerns and infrastructure in the study area, the interests of the stakeholders, and the purpose and application for the model. With this information, the model can be developed with the desired capabilities within an appropriate timeframe and budget.

MARKAL is a data intensive, systems analysis model. Details about New York City's energy and water system were added to the model to create a reference energy-water system (REWS). Table 2 lists the type of energy and water information needed to develop an integrated energy-water MARKAL model (WaterMARKAL). This table also lists potential information sources. We attempted to obtain as much of this information as possible to build the NYC Water-MARKAL from Steering Committee members, reports from NYCDEP and other New York City offices and agencies, Environmental Impact Statements, and published financial documents.

Once preliminary data were acquired, REWS construction began. Since all necessary data were not available, REWS development proceeded with preliminary data and concrete assumptions were supported by references and by consultations with Steering Committee members. All assumptions and data sources were securely stored in a database for future use. General descriptions of New York City water and energy data utilized for the NYC Water-MARKAL model are provided in Appendix E. 
Table 2. Typical data requirements for integrated water-MARKAL

\begin{tabular}{|c|c|c|c|}
\hline $\begin{array}{c}\text { Energy and Water } \\
\text { Systems } \\
\text { Components }\end{array}$ & Example & Data Needs & Data Sources \\
\hline Energy Resources & $\begin{array}{l}\text { coal, natural gas } \\
\text { surface water } \\
\text { and groundwater }\end{array}$ & amount of resource & $\begin{array}{l}\text { Energy Information Administration } \\
\text { Government agencies (local and state) } \\
\text { Nonprofit groups (Alliance to Save Energy, } \\
\text { World Bank) } \\
\text { United States Geological Survey } \\
\text { Environmental Impact Statements }\end{array}$ \\
\hline $\begin{array}{l}\text { Technologies } \\
\text {-Energy and water } \\
\text { resource extraction } \\
\text {-Energy resource } \\
\text { processing } \\
\text {-Power Plants } \\
\text {-Demand } \\
\text { technologies }\end{array}$ & $\begin{array}{l}\text { refineries, } \\
\text { conversion } \\
\text { plants } \\
\text { base-load and } \\
\text { peaking plants } \\
\text { air conditioner, } \\
\text { water heater, } \\
\text { vehicles }\end{array}$ & $\begin{array}{l}\text { investment costs } \\
\text { operating and } \\
\text { maintenance costs } \\
\text { lifetime of } \\
\text { technology } \\
\text { efficiency } \\
\text { capacity factor } \\
\text { energy use } \\
\text { water use } \\
\text { (withdrawals and } \\
\text { consumption) } \\
\text { energy production } \\
\text { water production } \\
\text { emissions }\end{array}$ & $\begin{array}{l}\text { Energy Information Administration } \\
\text { Owners/operators of power plants, refineries, } \\
\text { water and wastewater plants, mining operations } \\
\text { Government agencies (environmental protection } \\
\text { agencies, energy departments) } \\
\text { Scientific documents and reports } \\
\text { Universities and Laboratories } \\
\text { Environmental Impact Statements } \\
\text { Bond reports and other financial reports }\end{array}$ \\
\hline Materials & water, steel, etc. & $\begin{array}{l}\text { amount of material } \\
\text { (volume or weight) }\end{array}$ & $\begin{array}{l}\text { Industries } \\
\text { Government agencies } \\
\text { Scientific documents and reports }\end{array}$ \\
\hline
\end{tabular}

First, the energy system was further developed within the model to include the New York City steam system, and then information about the water and wastewater systems were added. The REWS development proceeded by constructing a less-detailed New York City energy-water system, and upon successful development and analysis, more detailed information was added to facilitate the analysis of proposed scenarios. Table 3 outlines the major components of a general Water-MARKAL REWS. Specialized windows-based software allows the modeler to input the location-specific data (see Table 2) and view the construction of the REWS. Changes and updates to the REWS can be immediately viewed.

Within a general REWS, technologies are classified as process, resource, conversion, or demand technologies. The flow and production of energy sources and materials are also modeled in the REWS. It is important to note that MARKAL requires balanced material flows. Therefore, a produced material must be completely consumed or utilized. EEEAG's approach models water and impaired water as a material. However, water lost through conveyance (i.e., leaking pipes or wasteful water use) can be accounted for through the transmission efficiency model parameter. Figure 3 illustrates the connections 
among various segments of the general REWS and an indication of the connections that can be captured by an integrated energy-water MARKAL model.

Table 3. Components of the general reference energy-water system

\begin{tabular}{|c|c|c|}
\hline $\begin{array}{c}\text { REWS } \\
\text { Components }\end{array}$ & Detailed Segments of REWS & Examples \\
\hline Resources & $\begin{array}{ll}\bullet & \text { Energy resources } \\
- & \text { Imported/Exported energy } \\
\text { and water resources } \\
\text { - } & \text { Extraction technologies } \\
- & \text { Freshwater sources } \\
& \\
\text { - } & \text { Impaired water }\end{array}$ & $\begin{array}{l}\text { - } \text { Oil, natural gas, coal } \\
\text { - } \quad \text { Natural gas, pipelines, water from a } \\
\text { shared source } \\
\text { - } \quad \text { Mining, Pumping of water } \\
\text { - } \quad \text { Surface water (lake, reservoirs, streams, } \\
\text { rivers) } \\
\text { - } \quad \text { Groundwater (aquifers, wells) } \\
\text { - } \quad \text { Sewer water, septic systems water, } \\
\text { storm water, runoff, etc. }\end{array}$ \\
\hline $\begin{array}{l}\text { Processing of } \\
\text { Resources }\end{array}$ & $\begin{array}{l}\text { - } \begin{array}{l}\text { Process technologies for energy } \\
\text { resources }\end{array} \\
\text { - } \quad \text { Converted energy resources } \\
\text { - } \quad \text { Water and wastewater treatment }\end{array}$ & $\begin{array}{l}\text { - } \quad \text { Refineries, biorefineries } \\
\text { - } \quad \text { Distillate fuel oil, gas } \\
\text { - Treatment plants, desalination, } \\
\text { membrane technology, filtration } \\
\end{array}$ \\
\hline $\begin{array}{l}\text { Generation } \\
\text { and } \\
\text { Transmission } \\
\end{array}$ & $\begin{array}{l}\text { - } \quad \text { Energy Production } \\
\text { - Water and Wastewater } \\
\text { conveyance } \\
\end{array}$ & $\begin{array}{l}\text { - Thermoelectric power plants } \\
\text { - Water pumping stations, water mains, } \\
\text { aqueducts and tunnels, water losses }\end{array}$ \\
\hline End-use & $\begin{array}{l}\text { - Sector demands for energy and } \\
\text { water } \\
\text { - } \quad \text { Demand technologies }\end{array}$ & $\begin{array}{l}\text { - Sectors: residential, commercial, } \\
\text { industrial, transportation, etc. } \\
\text { - Heating, air conditioning, } \\
\text { - Vehicles, hot water heater, clothes } \\
\text { washer, etc. }\end{array}$ \\
\hline
\end{tabular}




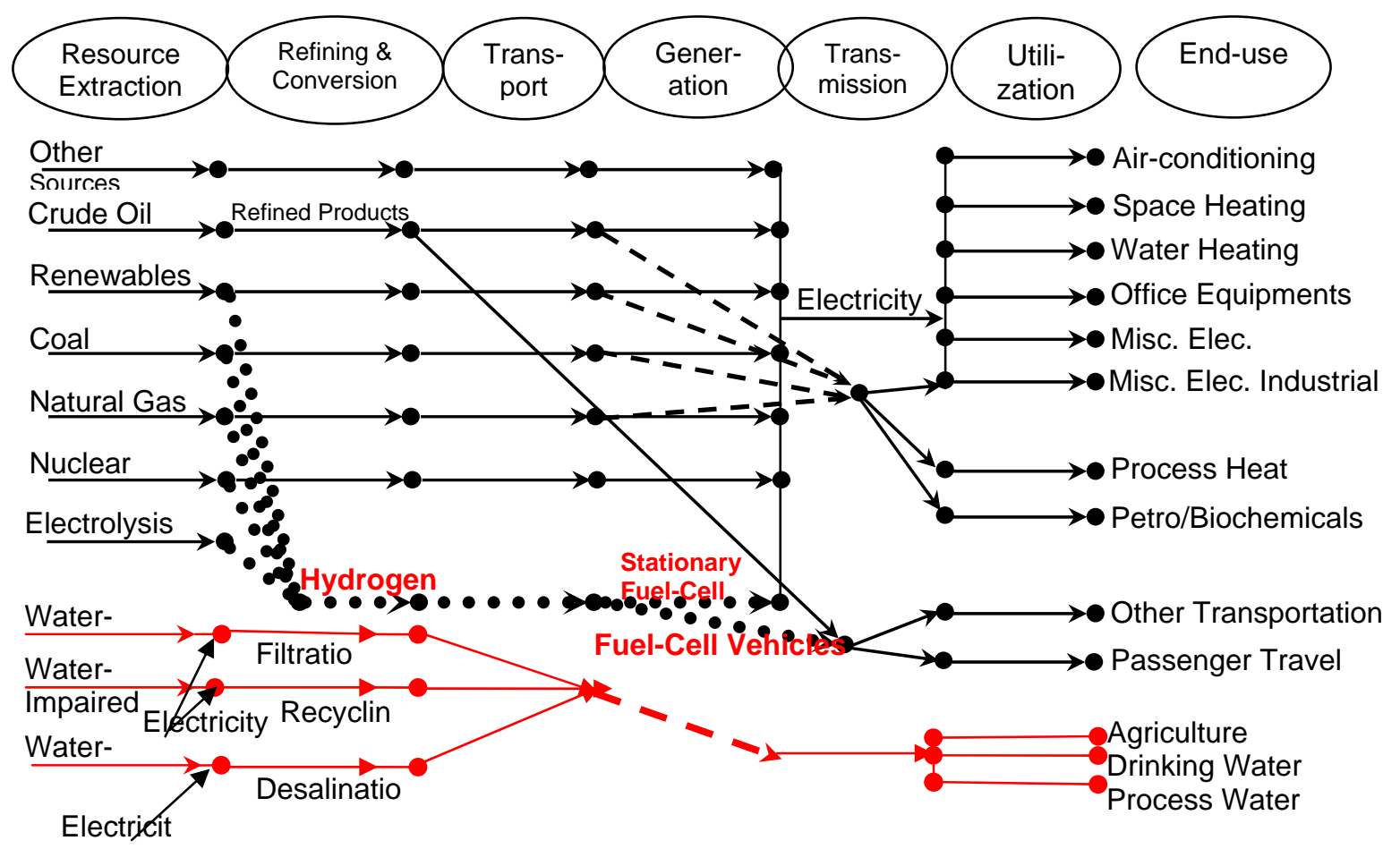

Figure 3. Generalized reference energy-water system in water-MARKAL

The careful design of an REWS will ultimately create a tailored, integrated energy-water decision support tool for a locale, region, or nation. Once fully developed, updates to the model can be easily made, and various scenarios can be studied to evaluate energy and water technologies, policies, and strategies for long-term integrated energy-water management.

We began development of the NYC Water-MARKAL by adding the specific water and wastewater segments of the REWS into the NYC-MARKAL model framework. At the same time, we worked with the Steering Committee members to define scenarios of interest that addressed stakeholder concerns related to the energy-water nexus. We worked to collect as much of the data required to set up and analyze the scenarios as possible, in conjunction with members of the Steering Committee.

While time constraints and data access prevented us from fully developing the NYC Water-MARKAL model during the period of the Pilot Study, we were able to make some test runs. We were also provided with some insight into the challenges of collecting the type of specific information that is required for detailed analysis in a quantitative model such as NYC Water-MARKAL.

\subsection{Application of NYC Water-MARKAL}

The MARKAL family of models is used traditionally to examine the most cost-effective (least system cost) energy system configuration, subject to external constraints, over the specified time horizon. Technologies compete to provide energy services, such as lighting, heating and cooling, transportation, etc. The model can be applied to any defined geographic area, as long as sufficient data at the appropriate level of detail are available. Flows of non-energy "materials" that are linked to the energy system, such as water, solid waste, nuclear materials, etc., can be calculated and used as constraints on the energy system solution. Emissions of greenhouse gas and criteria pollutants are calculated. After entering the detailed network structure of the water flows, depicted generally in the Reference Energy-Water System 
(REWS) in Figure 3, as well as additional energy and water technology data into the detailed NY WaterMARKAL model, we made several test runs of the model. The results illustrate simply some types of information that can be generated.

\subsubsection{Initial Model Test}

The initial model testing addresses a simple case: modeling the impacts of reduction in electricity demand for water heating. Three scenarios were tested, with presumed electricity demand reduction of $10 \%, 50 \%$ and $90 \%$, respectively. Such demand reduction can be achieved through efficiency improvements, cost reductions or a combination of both. With the reduction in electricity demand, decrease in $\mathrm{CO}_{2}$ emissions over the model time horizon is shown in Figure 4. The decrease in these emissions reflects the lowered generation of electricity by the mix of power plants that provide electricity to New York City. The reduction in total energy/water system costs (including the electricity supply infrastructure cost reductions) from the decreased electricity demand for water heating is depicted in Figure 5.

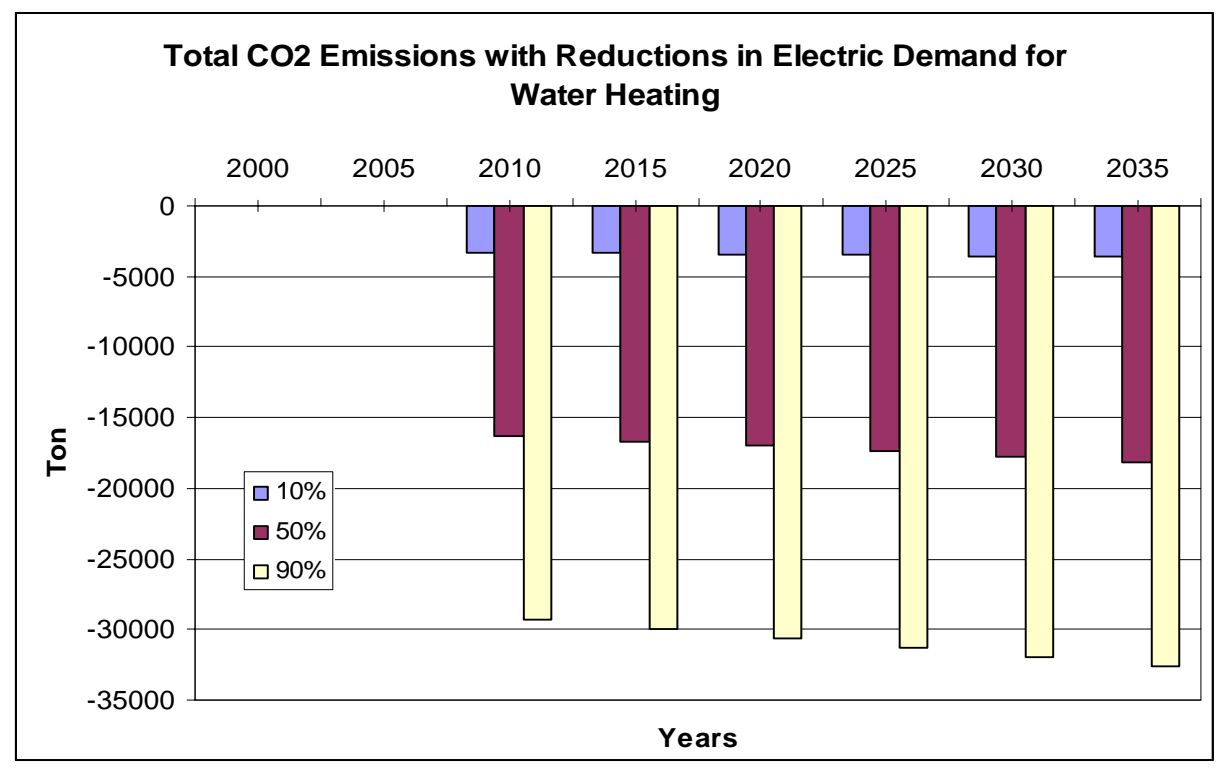

Figure 4. Total CO2 emissions with reductions in electric water heating demand 


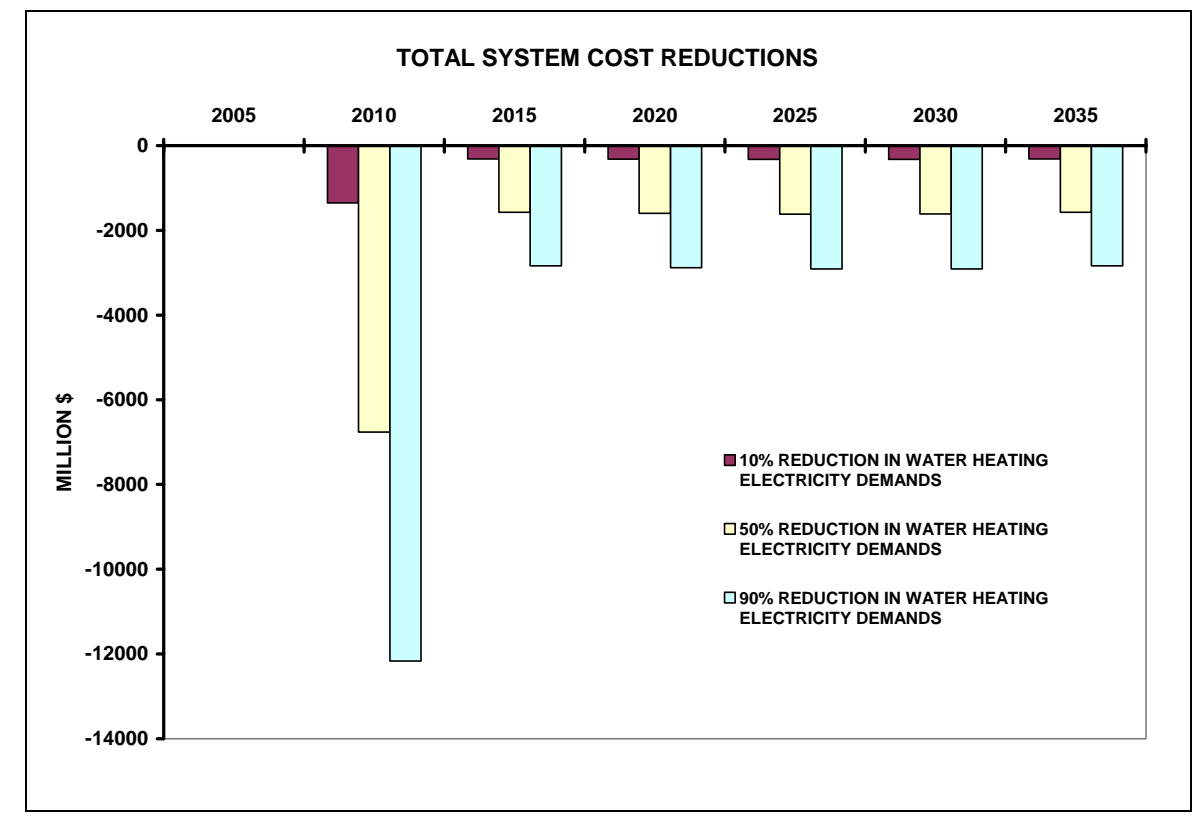

Figure 5. Total system cost reductions with decrease in electric water heating demand

Several energy-water integrated planning scenarios were developed with the members of the Steering Committee as candidates for proof-of-concept analysis using the newly-constructed NYC WaterMARKAL model. The scenarios were based on leading New York City energy and water issues identified by the Steering Committee and considered by them to be potentially interesting and useful applications. The Steering Committee members selected the following scenarios for initial analysis using the developed model:

- Scenario 1 - Water-Efficient Appliances: Evaluation of a proposed water conservation initiative involving front-load washer technology;

- Scenario 2 - Wastewater Treatment: Evaluation and comparison of energy production and emissions from NYC wastewater treatment plants;

- Scenario 3 - NYC Water Supply: Impacts of increased energy demands for the water supply system;

- Scenario 4 - NYC Steam: Evaluation of water supply and water use for NYC steam generation;

- Scenario 5 - Climate Change: The development of a plan to successfully link NYC WaterMARKAL to climate models and climate change research.

Because of our inability during the time frame of the project and the resources available to procure all the detailed data required, we were not able to complete the analyses for all scenarios. Some illustrative modeling results are available for Scenarios 1 and 2.

\subsubsection{Scenario 1 - Water-Efficient Appliances: Energy and Water Use Impacts}

A water conservation initiative is expected to begin in 2008 that will involve providing incentives for purchasing and installing water efficient washing machines. The energy and water savings of replacing top-load washers in multi-family dwellings and commercial laundries with EnergyStar ${ }^{\circledR}$ front-load washers was evaluated. The following assumptions were made: 
- According to the DOE Energy Information Administration (EIA) Residential Energy Consumption Survey (RECS), in the U.S. at least $75 \%-80 \%$ of households have a washer, so we assumed 75\% NYC households have a washer.

- $\quad$ According to the EIA RECS, about 5\% of households use front load washers and 95\% use top load washers.

- $\quad$ The EnergyStar estimate is 392 loads per year for one washer,

- $\quad 1$ washer per household is assumed.

The number of New York City households

- $\quad$ There are 3,021,588 New York City households based on 2000 US Census.

- $\quad$ The number of households increases by $1.1 \%$ each year.

A \$110 incentive for front load clothes washers is assumed.

Using the assumptions above, we examined four cases:

\section{Case 1:}

- $\quad 5 \%$ of washing demand is met by front load washer technology

- $\quad 95 \%$ of washing demand is met by top load washing technology

Case 2:

- $\quad 15 \%$ of washing demand is met by front load washer technology

- $\quad 85 \%$ of washing demand is met by top load washing technology

Case 3:

- $\quad 20 \%$ of washing demand is met by front load washer technology

- $\quad 80 \%$ of washing demand is met by top load washing technology

\section{Case 4:}

- $\quad 50 \%$ of washing demand is met by front load washer technology

- $\quad 50 \%$ of washing demand is met by top load washing technology

Substantial savings in water and electricity requirements as well as greenhouse gas emissions and criteria pollutants can be achieved by implementing policies to increase the use of efficient washer technologies. Figure 6 shows the water savings that can be anticipated as older, less water-efficient washers are changed out for newer, water efficient models. Figure 7 shows the equivalent expected electricity savings. Figure 8 shows the anticipated expected emission reductions. 


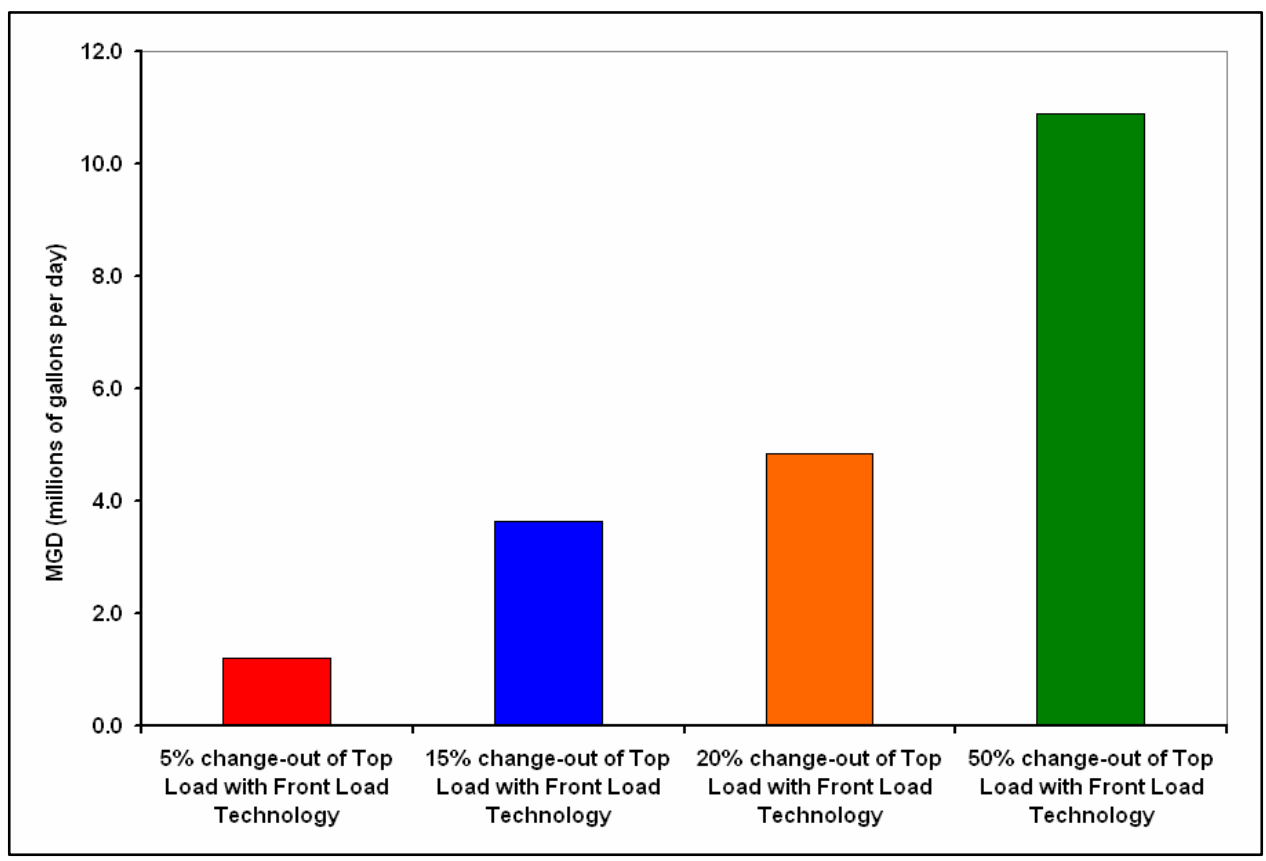

Figure 6. Water savings with efficient washers

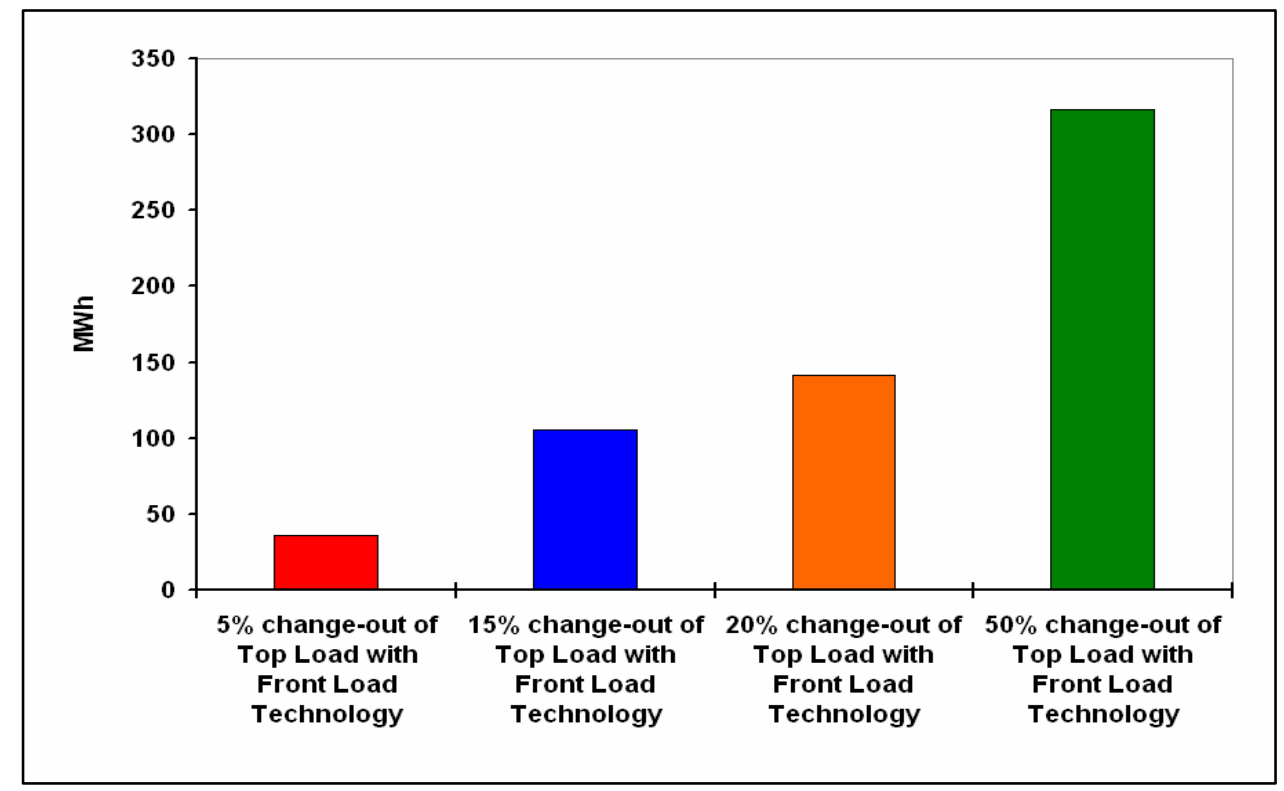

Figure 7. Electricity savings with efficient washers 


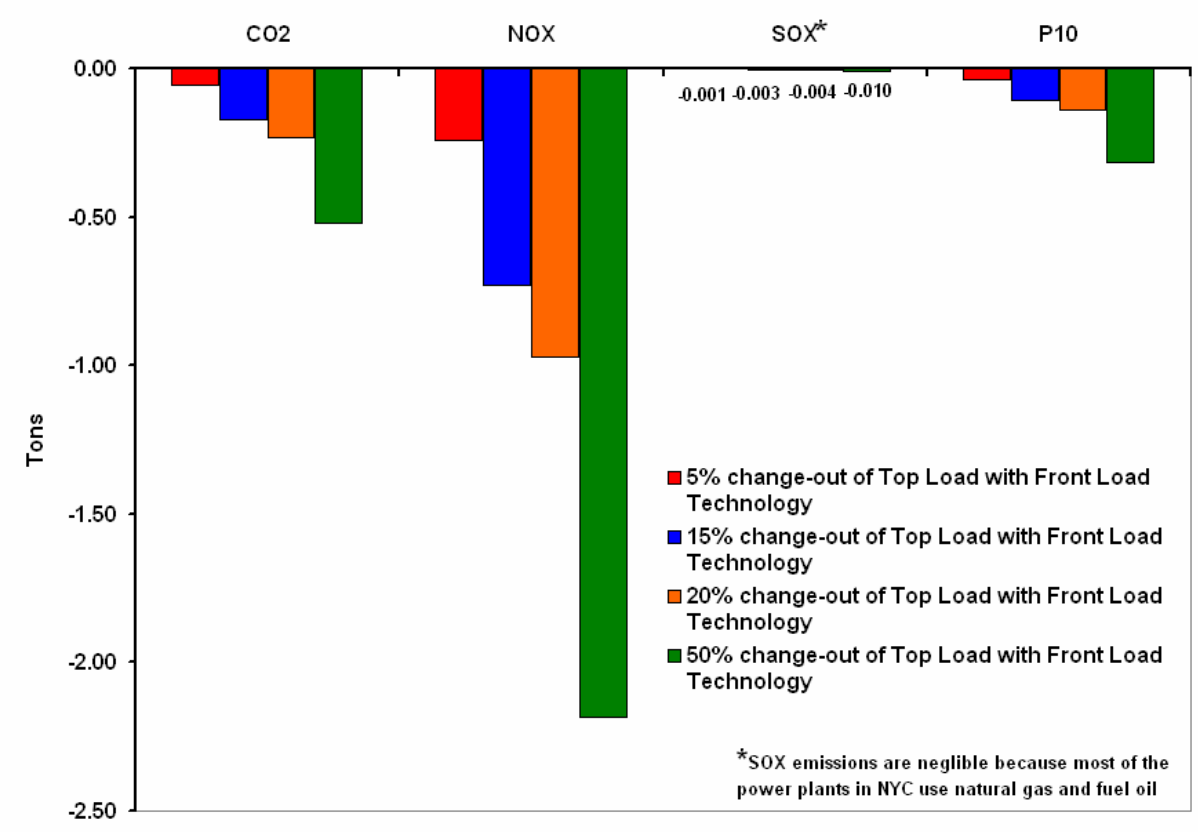

Figure 8. Emission reductions with efficient washers

One advantage of the Water-MARKAL methodology is that water, energy and emissions savings can be calculated over the time horizon of the model. Figure 9 shows those savings that can be anticipated from now until 2035.

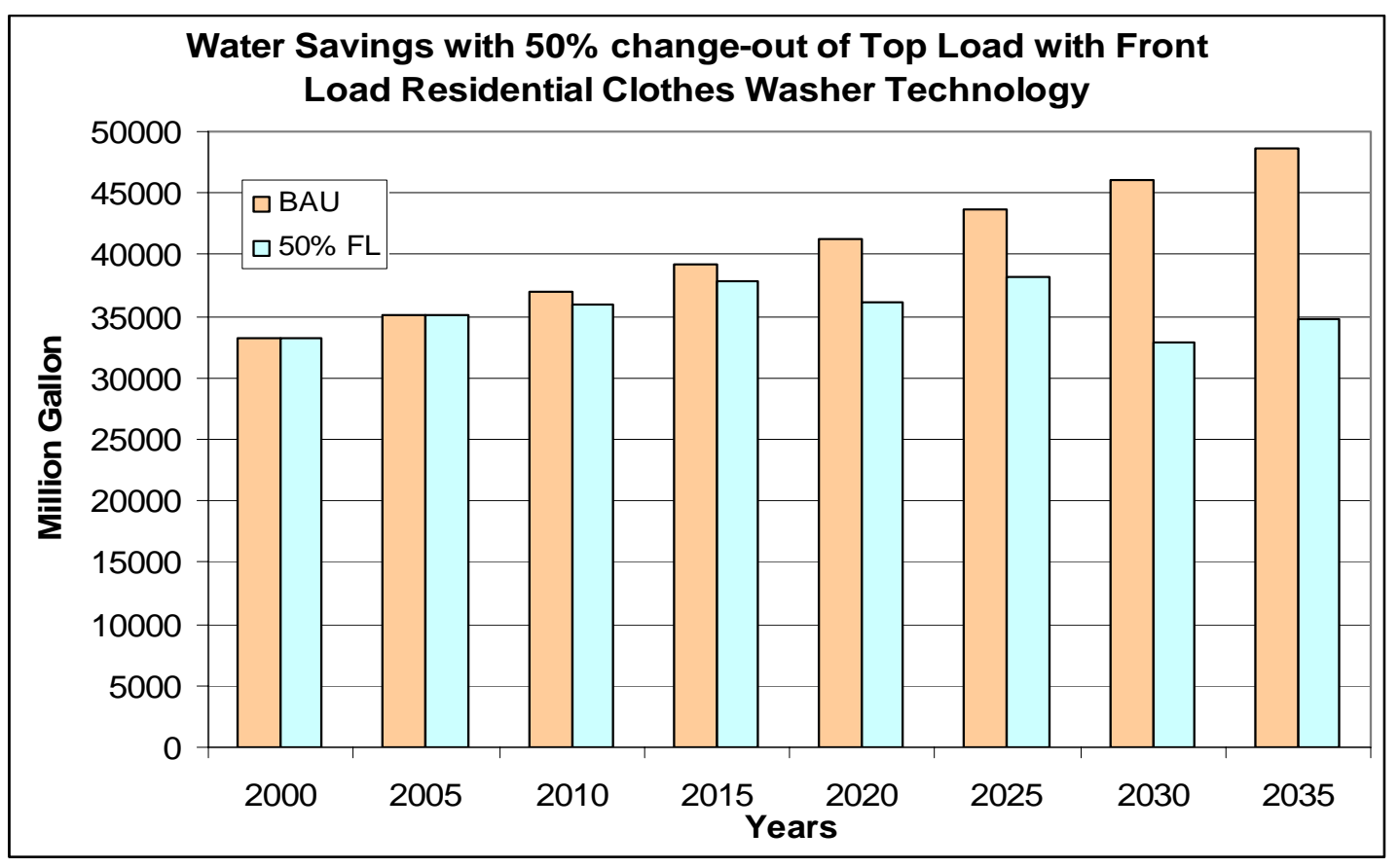

Figure 9. Long-term water savings with efficient washers 


\subsubsection{Scenario 2 - Wastewater Treatment: Deploying More Fuel Cells}

The New York City Department of Environmental Protection operates eight fuel cells totaling 1.6 MW of electricity capacity at four waste water treatment facilities (WWTFs) (see Table 4 below). The Steering Committee selected this scenario to explore the energy and environmental benefits of deploying additional fuel cells in WWTFs to produce electricity rather than flaring the digester gas.

WWTFs represent a growing niche for distributed generation. Many WWTFs utilize anaerobic decomposition to purify water prior to discharging it into a river or bay. According to U.S. Environmental Protection Agency (EPA 2006) about 21\% (or 544) U.S. WWTFs use anaerobic decomposition as part of their process. Less than $2 \%$ use anaerobic digester gas for energy production. USEPA estimates that if all 544 WWTFs in the United States that operate anaerobic digesters and have influent flow rates greater than 5 MGD were to install combined heat and power (CHP), approximately $340 \mathrm{MW}$ of clean electricity could be generated, offsetting 2.3 million metric tons of carbon dioxide emissions annually. Such reductions are equivalent to planting approximately 640,000 acres of forest, or the emissions of approximately 430,000 cars (EPA 2006). The potential benefits are high.

The New York City Department of Environmental Protection currently operates eight fuel cells of $200 \mathrm{~kW}$ each at four of their 14 WWTFs (Table 4). These cells were established in collaboration with the New York Power Authority, the New York State Energy Research Development Authority (NYSERDA), the U.S. Department Energy, and Fuel Cell Energy, Inc.

Table 4. NYC fuel cells at wastewater treatment facilities

\begin{tabular}{|l|l|l|l|l|}
\hline Location & $\begin{array}{l}\text { No. of Fuel } \\
\text { Cells - Fuel }\end{array}$ & $\begin{array}{l}\text { Size } \\
(\mathbf{k W})\end{array}$ & $\begin{array}{l}\text { Normal } \\
\text { Operation }\end{array}$ & Project Cost* \\
\hline $\begin{array}{l}\text { Red Hook WWTP, } \\
\text { Brooklyn }\end{array}$ & 2 - ADG & 400 & grid-parallel & \$2 Million \\
\hline $\begin{array}{l}\text { 26th Ward WWTP, } \\
\text { Brooklyn }\end{array}$ & 2 - ADG & 400 & grid-parallel & \$2 Million \\
\hline $\begin{array}{l}\text { Hunts Point WWTP, } \\
\text { Bronx }\end{array}$ & 3 - ADG & 600 & grid-parallel & \$3 Million \\
\hline $\begin{array}{l}\text { Oakwood Beach WWTP, } \\
\text { Staten Island }\end{array}$ & 1 - ADG & 200 & grid-parallel & \$1 Million \\
\hline Total & 8 & 1,600 & & \\
\hline
\end{tabular}

Source: NYPA, 2008 and NYSERDA, 2005.

Each of the eight fuel cells operates on anaerobic digester gas instead of consuming natural gas. By running on digester gas produced by the anaerobic treatment of waste water, the fuel cells make use of a fuel source that would otherwise be disposed of through flaring. Heat generated by the fuel cells is recovered and used to support and maintain the anaerobic digestion process at the wastewater treatment plants and produces hot water for space heating and domestic use (NYCDEP 2008 and NYPA 2008). Figure 10 presents a simplified schematic of a fuel cell power system (Torpey 2002). 


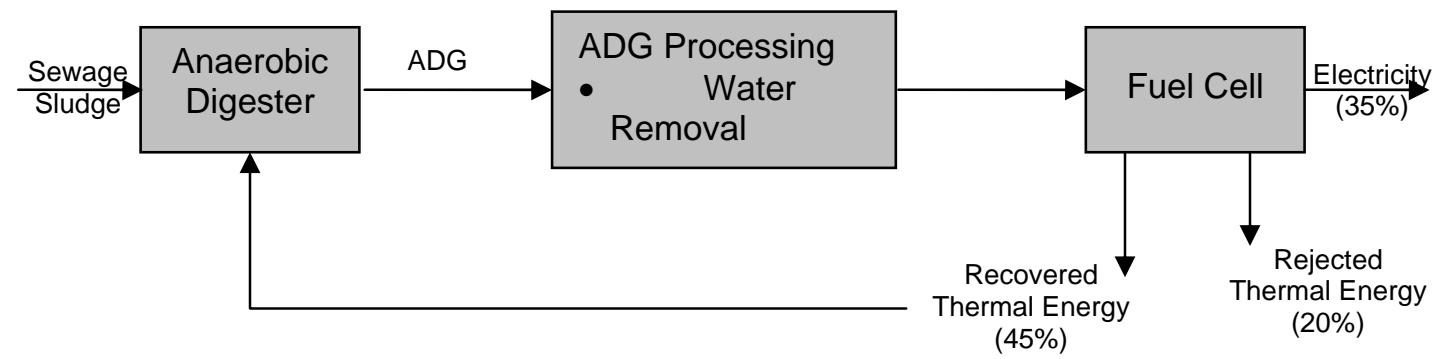

Source: Modified from Torpey 2002

Figure 10. Wastewater treatment facility - fuel cell system schematic

The fuel cells operate at an average efficiency of 78 percent and use 38 percent less fuel than typical onsite fossil-based thermal generation and purchased electricity. The environmental benefits of fuel cells are significant. Broad fuel cell market penetration and elimination of ADG flaring should result in substantial reductions in emissions of major regulated air pollutants. It was calculated by Kishinevsky and Zelingher (2003) that eight fuel cells operating at NYCDEP WWTFs would assure that NYPA met its "zero net emissions" goals.

Some illustrative results from employing Water-MARKAL to estimate the system-wide impacts of deploying additional fuel cells at WWTFs are presented below. As noted above, the expected benefits include reducing NYCDEP's reliance on grid power, increasing in-city generation, and lowering emissions.

In this analysis we assume that nearly $33 \mathrm{MW}$ of fuel cell capacity can be established at NYCDEP WWTFs by 2025 (Figure 11). We assume a capital cost for new fuel cells of $\$ 5000 / \mathrm{kW}$ and 3 cents $/ \mathrm{kWh}$ for maintenance (EPA 2006 and NYPA 2008). While this example assumes up-front an installed capacity for fuel cells by 2025, the model also is capable of competing fuel cells with other technologies in the energy/water market to determine new capacity under market conditions, with or without incentives. That analysis can be performed in the future.

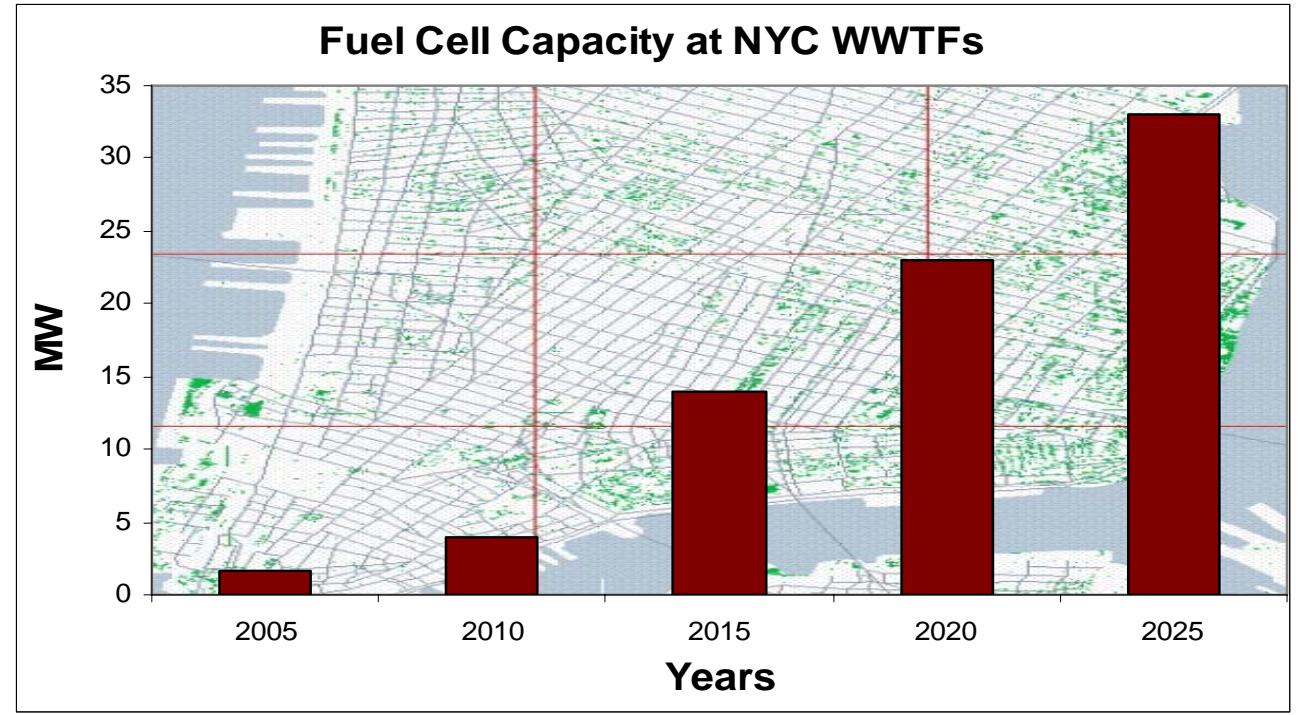

Figure 11. Projected fuel cell capacity at NYC WWTFs 
The MARKAL results represented below calculate the system-wide emission reductions achieved across the New York City electricity system by deploying fuel cells at waste water treatment facilities. Figure 12 estimates CO2 emissions reductions, whereas Figure 13 represents other criteria pollutants.

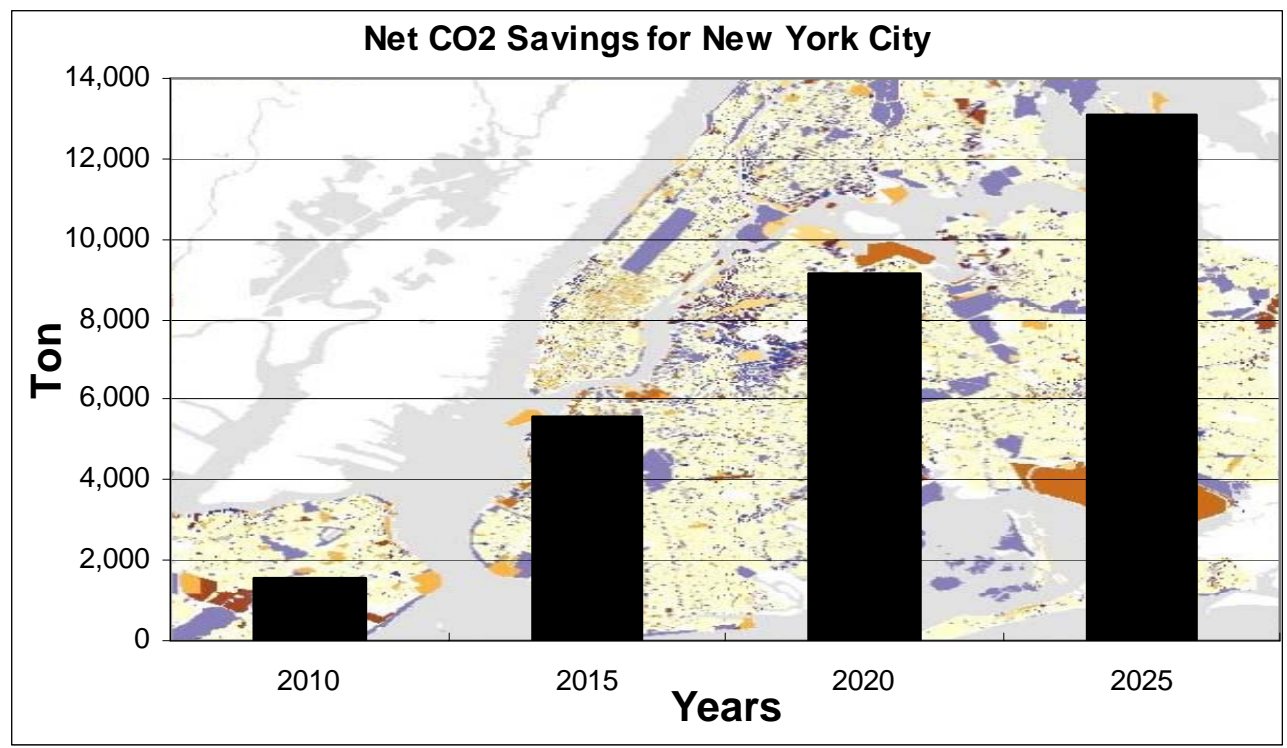

Figure 12. Net reduction in $\mathrm{CO} 2$

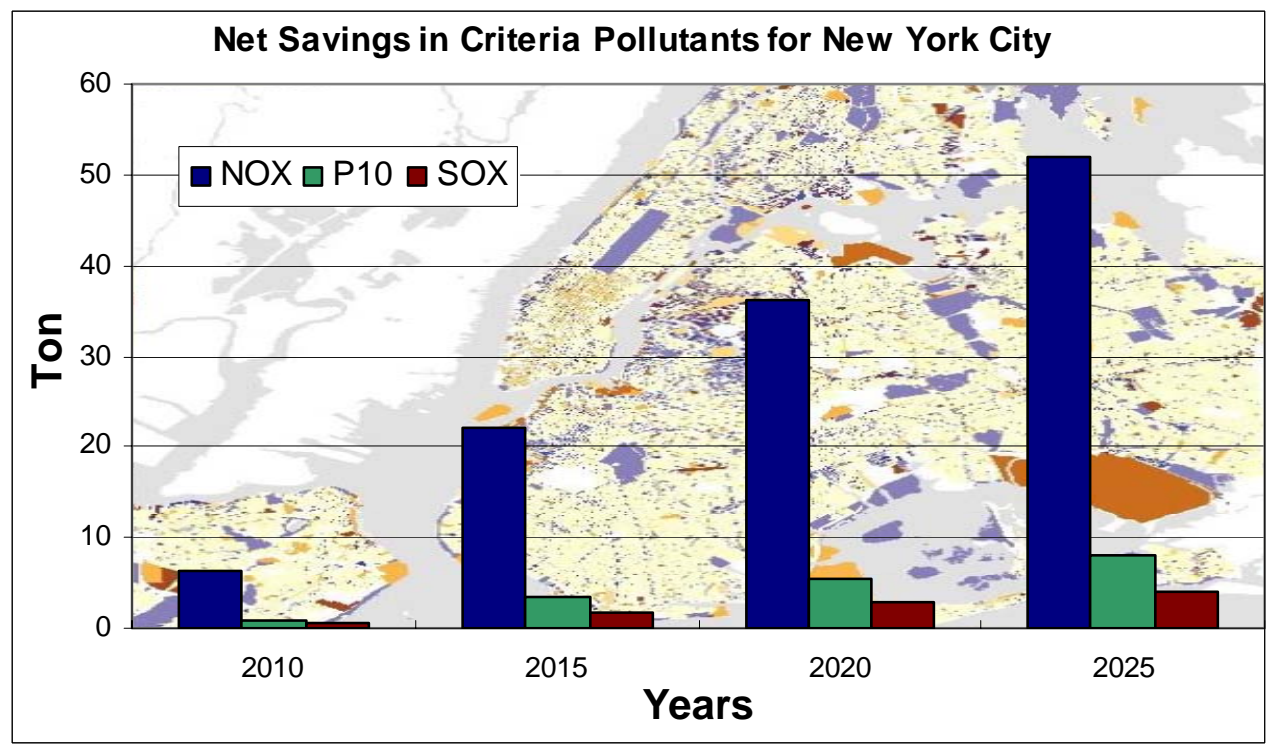

Figure 13. Net reduction in criteria pollutants 


\subsubsection{Scenario 3 - New York City Water Supply: Impacts of Increased Energy Demand for New Treatment}

New York City authorities may be required to add new water treatment facilities to treat the water in the New York City water supply system. UV water treatment and filtration could be implemented in the water system within the next 20-30 years. This scenario was defined to evaluate the increase in energy demands that new alternative water treatment options would require over the present system. This scenario as defined would investigate the impacts of implementing such treatment on the NYC energy system and resulting air emissions. The energy impacts of filtering additional water from the Delaware and Catskill water supplies would also be analyzed.

Preliminary information about these systems was obtained from environmental impact statements and design information on the NYC DEP website. Specifically, the costs and energy use for the proposed UV treatment system and Croton Filtration plant were considered. Efforts are ongoing to obtain additional information to model this scenario in the future, outside this project.

\subsubsection{Scenario 4 - New York City Steam Generation: Water Supply and Energy Impacts}

The New York City steam system takes water from the New York City water system to produce steam. The water must receive pretreatment to obtain water quality useful for steam production. Two steam generation technologies are used in the New York City steam system: traditional and truncated combined cycle. This scenario as defined would compare the water use, steam production efficiency, and costs of both technologies while evaluating the impacts of source water quality and steam demands on the energy and water systems.

Modeling this scenario requires specific information from New York City, including: the amount of water (in million gallons) used by New York City steam production plants; the steam output of the plants (lbs); the amount (in million gallons) and discharge locations of water flow resulting from condensed steam; and operating and maintenance costs of the steam system.

Generalized information providing bulk steam output can be obtained from Consolidated Edison annual reports; however, more detailed information is needed. Data at this level of detail needs to be obtained directly from Consolidated Edison, Inc. steam operations. Such information is deemed proprietary and the importance of securing and safely utilizing such information is crucial. Contact with Consolidated Edison, Inc. led to ongoing discussions to obtain approval for the use of steam operations data for our modeling efforts. We were unable to obtain approval for dissemination and use of the steam operations data within the timeframe of this study. This highlights the need for access to data for energy-water systems and sufficient lead time for procuring data when working with various institutions.

\subsubsection{Scenario 5 - Climate Change Models and Research: A link with Energy and Water}

Climate change impacts affect energy and water systems. The MARKAL modeling framework can track emissions that lead to global warming. To adequately capture the effects of climate change on energy and water systems, MARKAL inputs can be linked to climate model outputs, and climate-sensitive information and parameters can be added to the MARKAL modeling framework (e.g., reservoir levels). In a previous project, we evaluated the impacts of a one or two degree temperature decrease on the New York City energy system, in order to gain understanding of the sensitivity of the MARKAL model to temperature (Carroll et. al. 2005). This decrease in temperature led to energy savings, emission reductions, and total energy system cost savings. In the future, we plan to evaluate the impacts of a set of threshold levels (e.g., 1 to $4^{\circ} \mathrm{C}$ increase in temperature) on New York City energy and water systems (e.g., 
water reservoir levels, efficiency of energy production). Projected changes in precipitation will be tested as well, both separately and in combination with temperature increases.

This scenario was intended to build on the previous work by producing a scoping plan that describes how to incorporate climate issues into NYC Water-MARKAL for longer-term planning, an issue that the Steering Committee Members felt was important to address given New York City's vulnerability to rising sea levels. This plan will be developed outside this project due to resource and time limitations. 


\section{SUMMARY AND RECOMMENDATIONS}

Brookhaven National Laboratory researchers, with substantive input from the Pilot Study Steering Committee members, identified many energy and water and integrated planning challenges in New York City. The Committee suggested useful scenarios that they would like to see addressed at the energy-water nexus. BNL then defined an integrated energy-water decision support tool, building on the foundation of an existing NYC MARKAL energy model, to analyze the proposed scenarios. The Committee critiqued the Pilot Study process and helped to define the study findings. Finally, the Committee made recommendations on possible future work.

\subsection{New York City Planning Challenges}

The following energy and water issues and integrated planning challenges were identified by the Steering Committee members and BNL researchers:

- There is a lack of an official, centralized energy entity/board with the power to manage the New York City energy system and facilitate integrated planning;

- Integrated planning between New York City's energy and water sectors primarily occurs on a projectspecific basis. Long-term integrated planning would be useful.

- Presently, demands from the water sector for energy require Consolidated Edison, Inc. to react and alter peak load plans and budgets to ensure that the water supply sector gets the energy it needs.

- There are increasing energy requirements to ensure the reliable operation of New York City drinking water and wastewater systems (e.g. increased UV treatment and operation of the Croton filtration plant on the New York City energy system).

- Steam production for the NYC district heating system requires both energy availability and water withdrawal planning.

- At present New York City officials are not able to enforce water conservation measures and to assess the total benefits in water and energy savings of those water conservation initiatives.

- There is increasing concern about climate change impacts (e.g. sea level rise, increases in storm intensity, flooding) on energy production (e.g., efficiency of energy generation, energy demands, emissions from power production) and on the New York City wastewater treatment plants and the sewer system.

- Acquisition of energy and water data at the level of specificity needed to provide the answers sought by the affected stakeholders for their specific interests is difficult.

\subsection{New York City Energy-Water Scenarios}

Several energy-water integrated planning scenarios were developed as candidates for a proof-of-concept analysis using the newly-constructed NYC Water-MARKAL model. The five scenarios below were selected from a larger list as representative of issues that require integrated energy-water planning and that could test the decision support tool formulation.

- Scenario 1 - Water-efficient Appliances: Evaluation of the energy and water impacts from a proposed water conservation initiative involving front-load washer technology;

- Scenario 2 - Wastewater Treatment: Evaluation and comparison of energy production and emissions from NYC wastewater treatment plants;

- Scenario 3 - NYC Water Supply: Impacts on the energy supply system of increased energy demands for the water supply system; 
- Scenario 4 - NYC Steam: Evaluation of water supply and water use for NYC steam generation;

- Scenario 5 - Climate Change: The development of a plan to successfully link NYC WaterMARKAL to climate models and climate change research.

\subsection{Decision Tool Application - Proof-of-Concept}

The Steering Committee emphasized throughout the study that addressing New York City energy-water issues will require more long-term, integrated planning and an enhanced capacity to direct such planning. Through the collaboration under this pilot study, a decision-support tool, the NYC Water-MARKAL model, was developed in initial form to analyze scenarios related to critical energy and water issues outlined by the Pilot Study Steering Committee. Data were obtained from reports, Steering Committee members, and databases to facilitate the modeling effort.

The development and application of Water-MARKAL was by necessity initial, but indicative of what could be accomplished with additional resources and time. An expanded approach, as suggested by the Steering Committee members, could assist government agencies and offices, companies, non-profit groups, and others to solve energy and water issues of New York City by providing information about the energy, water, environmental, and economic benefits in a common framework. In addition, the ability to link Water-MARKAL to other modeling programs would be a strong attribute, thus providing a longterm, energy-water decision-support tool capable of multi-scale analysis (local, watershed, state, regional) with flexible data metrics and parameters.

While the study was successful in providing a proof-of-concept for the Water-MARKAL decision support tool, during the course of developing the scenarios it became evident that collection of specific data from multiple involved stakeholders is difficult due to various legal, proprietary and other concerns. Given more time and resources, either these concerns could be overcome or where they could not or data were not available, generic data could be developed for use in the scenarios. In any case, to complete the analyses of the scenarios defined above, more data are needed.

\subsection{The Role of the Steering Committee}

The Steering Committee members significantly invested their time in the pilot study activities. Their expertise and interactions were essential to the successful completion of the pilot study objectives. The Steering Committee members expressed satisfaction with the level and methods of interaction utilized to complete the project (two day-long meetings, three conference calls, e-mail and phone contact). The study was a volunteer effort for the members, and they expressed appreciation for the project's organization and methodology, designed to maximize their contributions in minimum required time. Several of the Steering Committee members suggested a similar approach could be used to facilitate integrated planning collaborations among other energy and water agencies.

\subsection{Future Work and Recommendations}

The Steering Committee suggested that in the future it would be valuable to continue developing the NYC Water-MARKAL model as described above, and with more detailed data about energy and water systems and climate sensitive parameters. To help address the difficulty of obtaining facility and location-specific data, some generic information could be developed and used when necessary. The tool could also be enhanced by linking it to watershed/water quality models, geographic information systems software, and climate models. Expanding the model to incorporate Long Island's (NY) unique energy and water issues and links to the New York metropolitan region was also suggested. 
Some additional scenarios of immediate interest were suggested, including:

- distributed generation and combined heat and power at wastewater facilities;

- environmental and economic impacts of renewable energy options;

- environmental and economic impacts of water reuse strategies;

- impacts of disruptions in the natural gas system due to increased flooding (possibly caused by climate change); and

- comparisons of emissions reduction strategies implemented throughout New York City.

The development and application of a Water-MARKAL for other metropolitan areas was discussed favorably.

Overall, the Steering Committee expressed interest in following the progress and future direction of the energy-water activities (Report to Congress, roadmapping efforts, pilot studies) initiated by the DOE. The Committee members made some suggestions on what a possible future in this area could look like. Their suggestions included the establishment of an official Energy-Water Nexus program chaired by the U.S. DOE and managed by a collaborative committee comprised of interested government agencies, industry, professional societies, foundations, and other relevant groups (e.g., United States Geological Survey, Environmental Protection Agency, American Society of Civil Engineers, Electric Power Research Institute, etc.).

Alternatively the establishment of an interagency Energy-Water Nexus program could be established similar to the U.S. Climate Change Science Program that is sponsored by thirteen federal agencies and managed by the Office of Science and Technology Policy, Council on Environmental Quality, National Economic Council, and the Office of Management and Budget. Perhaps the establishment and funding for such a committee or interagency program could come from the U.S. Congress or Executive Branch. Such a committee or agency could provide direction for energy and water research, technology development, and planning activities in the United States. 


\section{REFERENCES}

ASE Watergy: Taking Advantage of Untapped Energy and Water Efficiency Opportunities in Municipal Water Systems, Washington, D.C., Alliance to Save Energy, 2002.

American Water Works Association Research Foundation and California Energy Commission, Water and Wastewater Industry Energy Efficiency: A Research Roadmap. Denver, CO, 2004.

http://www.energy.ca.gov/pier/iaw/descriptions/50001040ROADMAP.PDF

Brookhaven National Laboratory, The Electric Power Research Institute, and The Earth Institute at Columbia University, Proceedings of the New York Regional Energy-Water Workshop, Editor: A. Reisman, New York City , April 20, 2004, http://www.bnl.gov/est/waternexusinitiative.asp

Carroll, O.; Bhatt, V.; Lee, J., Framework for Energy/Building/Urban Heat Island Analysis, Final Report under USEPA Agreement No. NP982879030, Stony Brook, NY, September 30, 2005.

Columbia University, Columbia Environmental Stewardship: Operation Save New York, New York City, NY, 2007, http://www.columbia.edu/cu/environment/news/DemandResponse/index.html

Con Edison Inc., Con Edison, Inc. 2006 Annual Report. New York City, 2007a, http://media.corporate-ir.net/media_files/irol/61/61493/reports/2006Annual\%20Report.pdf, http://www.coned.com/aboutus/.

Con Edison Inc., Con Edison Details \$1.4 Billion in Electric Delivery Investments and New Emergency Response Initiatives for Summer, March 2007, http://investor.conedison.com/phoenix.zhtml?c=61493\&p=irol-newsArticle\&ID=977919\&highlight=.

Con Edison Inc., Operation Kill-A-Watt to Pay for \$10 million in Energy Efficiency Upgrades for New York City Buildings in 2007, February 2007, http://www.publicenergysolutions.com/news/releases-kill_a_watt-1-22-07.php, http://www.publicenergysolutions.com/news/releases-westchester2-7-07.php.

Con Edison Inc., Steam System, March 2007, http://www.coned.com/newsroom/energysystems_steam.asp

DOE Energy Demands on Water Resources: Report to Congress on the Interdependency of Energy and Water. Washington, D.C., U.S. Department of Energy, 2006, http://www.sandia.gov/energy-water/docs/121-RptToCongress-EWwEIAcomments-FINAL.pdf.

DOE, CHP Case Studies in the Pacific Northwest, Columbia Boulevard Wastewater Treatment Plant, U.S. Department of Energy. 2008, www.eere.energy.gov/de/pdfs/cs_columbia_blvd.pdf

ECS, Operation Save New York. Energy Curtailment Specialists Inc., Creator and Administrator of Operation Save New York, New York City and Buffalo, NY, 2007, http://www.ecsny.com/index.php

EEEAG, Energy-Water Nexus Initiative, Presentation that includes discussion of the early definition and development of an energy-water decision tool: Water-MARKAL, Brookhaven National Laboratory, September, 2006. 
Environmental Protection Agency, Opportunities for and Benefits of Combined Heat and Power at Wastewater Treatment Facilities, U.S. Environmental Protection Agency Combined Heat and Power Partnership, 2006, http://www.epa.gov/chp/documents/wwtf opportunities.pdf

Energy-Water Nexus, The Energy-Water Nexus: A Strategy for Energy and Water Security. A multiDOE national laboratory initiative, Sandia National Laboratories, Team Project Lead, 2007. http://www.sandia.gov/energy-water/

Hamilton, L., Goldstein, G., Lee, J., et. al, MARKAL-MACRO: An Overview, Brookhaven National Laboratory. Report BNL-48377, 1992.

Hill, D. and R. Goldberg, Energy Demand, Contributed to Rosenzweig. C. and W.D. Solecki (Eds.), "Climate Change and a Global City: The Potential Consequences of Climate Variability and Change Metro East Coast” Report for the U.S. Global Change Research Program, National Assessment of the Potential Consequences of Climate Variability and Change for the United States, Columbia Earth Institute New York, pp. 121-148, 2001.

IPCC, Intergovernmental Panel on Climate Change. Contribution of Working Group II. Climate Change 2007: Impacts, Adaptation and Vulnerability. Summary for Policymakers, Geneva, 23pp, 2007a.

Intergovernmental Panel on Climate Change, Contribution of Working Group I, Climate Change 2007: The Physical Science Basis, Summary for Policymakers, Geneva. 21pp., 2007b.

Kishinevsky, Y. and S. ZelingheComing, Clean with Fuel Cells: An Innovative Emission-Offset Project That Utilizes Anaerobic Digester Gas-Powered Fuel Cells to Produce Electricity, IEEE Power \& Energy, 1540-7977/03/2003 IEEE, November/December 2003.

Loulou, R., G. Goldstein, and K. Noble (2004), Documentation for the MARKAL Family of Models. Available from Energy Technology Systems Analysis Programme, http://www.etsap.org/tools.htm.

National Energy Technology Laboratory, E\&WR - Water-Energy Interface Cooling Water Intake Structures, 2006, http://www.netl.doe.gov/technologies/coalpower/ewr/water/policy/cwis.html

NYC Energy Policy Task Force, New York City Energy Policy: An Electricity Resource Roadmap. New York City, 2004, http://www.nyc.gov/html/om/pdf/energy_task_force.pdf, http://www.nycedc.com/NR/rdonlyres/B418F914-9905-4DDE-BA0730C52B1EB2E9/0/2006StatusReportFINAL061406.pdf

New York City, Mayor's Office of Long-term Planning and Sustainability PlaNYC: A Greener, Greater New York. New York City (NYC), 2007a, http://www.nyc.gov/html/planyc2030/downloads/pdf/full_report.pdf.

New York City, Mayor's Office of Long-Term Planning and Sustainability, Inventory of New York City Greenhouse Gas Emissions, 2007b, http://www.nyc.gov/html/om/pdf/ccp_report041007.pdf.

New York City Department of City Planning, New York City Population Projections by Age/Sex and Borough, 2000-2030, New York City, 2006, http://www.nyc.gov/html/dcp/html/census/popproj.shtml 
New York City Department of City Planning, New York City Department of City Planning (NYCDCP) Land Use Facts. February 2007a, http://home2.nyc.gov/html/dcp/html/landusefacts/landusefactshome.shtml

New York City Department of City Planning, New York City Department of City Planning, May 2007b, http://www.nyc.gov/html/dcp/home.html.

New York City Department of City Planning, 2001 NY Harbor Water Quality Report and Summaries of NYC Sewage Plant Info on Dry Flow and Capacity, New York City, NY, 2001 New York City

Department of Environmental Protection, 2001

New York City Department of City Planning, The Catskill/Delaware Ultraviolet Light Disinfection Facility Final Environmental Impact Statement, New York City, N.Y., 2004a, New York City Department of Environmental Protection, April 2007, http://www.nyc.gov/html/dep/html/catdeluv.html.

New York City Department of City Planning, The Croton Filter Plant Project Final Supplemental Environmental Impact Statement, 2004b, New York City Department of Environmental Protection, 2004, http://www.nyc.gov/html/dep/html/crotoneis.html

New York City Department of City Planning, New York City 2005 Drinking Water Supply and Quality Report, 2005a New York City, New York City Department of Environmental Protection, 2005, http://www.nyc.gov/html/dep/pdf/wsstat05.pdf, http://www.nyc.gov/html/dep/html/wsstate.html.

New York City Department of City Planning, Adapting NYC's Water and Wastewater Treatment Systems to Climate Change, 2005b. E. Lloyd Presentation at the U.S. Climate Change Science Workshop, Arlington, VA November 15, 2005, http://www.climatescience.gov/workshop2005/presentations/WA2.5 Lloyd.pdf

New York City Department of City Planning, New York City's Wastewater Treatment System. New York City, 2006, New York City Department of Environmental Protection 2006, http://www.nyc.gov/html/dep/pdf/wwsystem.pdf.

New York City Department of City Planning, New York City's Wastewater Treatment System 2008, New York City Department of Environmental Protection, 2008. http://nyc.gov/html/dep/pdf/wwsystem.pdf

New York City Municipal Finance Authority, The New York City Water and Sewer System: A Component of the City of New York: Comprehensive Annual Financial Report for the Fiscal Year Ended June 30th, 2006, New York City, 2006.

New York Independent System Operator, Comprehensive Reliability Planning Process: 2007 Reliability Needs Assessment, Rensselaer, N.Y., 2007a, http://www.nyiso.com/public/webdocs/services/planning/reliability_assessments/2004_planning trans_report/2007_RNA.pdf

New York Independent System Operator, Upstate-Downstate Study with findings and Recommendations, Rensselaer, N.Y., 2007b, http://www.nyiso.com/public/webdocs/services/planning/resource_adequacy/2007_Upstate_Dow nstate_Study_Report.pdf 
New York Power Authority, New York Power Authority New Technology Programs-Fuel Cells, April 2007, http://www.nypa.gov/services/fuel\%20cells.htm, http://www.nypa.gov/services/fuel\%20cell\%20projects.htm.

New York Power Authority, Information collected from two programs websites: PowerNow! Small, Clean Plants and New Technology Programs-Fuel Cells, 2008, http://www.nypa.gov/facilities/powernow.htm and http://www.nypa.gov/services/fuel\%20cells.htm

New York State Energy Research and Development Authority, New York State Hydrogen Energy Roadmap, Albany, N.Y., 2005.

Potorti, D., Environmental Engineering: Challenging and Rewarding in Clearwaters, New York Water Environment Association, Inc., April 2007, http://www.nywea.org/clearwaters/04-fall/EnvEng.cfm.

Protopapas, Angelos L., Combined sewer overflow abatement: The East River project. Water Resources Management, 13(2): 133-151, 1999.

Rosenzweig C, W. Solecki, Climate Change and a Global City: The Potential Consequences of Climate Variability and Change, Metro East Coast. Report for the U.S. Global Change Research Program, Columbia Earth Institute, New York, 2001.

Rosenzweig, C., D.C. Major, K. Demong, et.al, Managing climate change risks in New York City's water system: Assessment and adaptation planning, Mitig. Adapt. Strategies Global Change, 12, 1391-1409, 2007.

SBW Consulting, Inc., Municipal Water Treatment Plant Energy Baseline Study, Bellevue, WA, 2006, http://www.pge.com/docs/pdfs/biz/rebates/water treatment/WaterTreatmentBaselineStudyReport.pdf.

Torpey, M., Renewable Electricity Production and Reduced Air Emissions at Wastewater Treatment Plants, Environmental Quality Management, Spring 2002, pp 99-102, Wiley Periodicals, Inc.

United Nations, UN World Water Development Report: Water for People, Water for Life, Paris, New York, Oxford University, UNESCO and Berghahn Books, 2003, http://www.unesco.org/water/wwap/wwdr1/.

United States Geological Survey, USGS Circular 1268: Estimated Use of Water in the United States in 2000, Washington, D.C., 2004, http://pubs.usgs.gov/circ/2004/circ1268/pdf/circular1268.pdf

Van Lenten, C., Storm Surge Barriers for New York Harbor?, New York Academy of Sciences Website, Posted November 6, 2005. 


\section{APPENDIX A \\ SUPPLEMENTAL INFORMATION AND SOURCES}




\section{CLIMATE CHANGE}

\section{$\underline{\text { Press Articles }}$}

“New York City Takes its Greenhouse Gas Weight”

Type: Press article

By: Associated Press

Published: 2007

Link: http://www.msnbc.msn.com/id/18054971/from/RS.5/,

http://www.nyc.gov/html/om/pdf/ccp_report041007.pdf

Description: This article reports the findings of NYC's Greenhouse Gas Inventory that was completed by the Office of Long-Term Planning and Sustainability. The second link is for the actual report.

\section{"Global Warming May Put U.S. in Hot Water"}

Type: Press article

By: USA Today - Borenstein, S.

Published: April 17, 2007

Link: http://www.usatoday.com/tech/science/2007-04-16-global-warming-water_N.htm?csp=34

Description: U.S. scientists and military experts stated that global warming will also lead to water issues such as water shortages, flooding, and more intense storms. In particular for New York City, Cynthia Rosenzweig stated, "the No. 1 vulnerability for the metropolitan East Coast" will be storm surge from rising sea levels.

\section{"Hell Looms! Study Predicts Heat Waves, Fires, and Flooded Manhattan"}

Type: Press article

By: New York Daily News - Boyle, C.

Published: April 7, 2007

Link: http://www.nydailynews.com/news/wn_report/2007/04/07/2007-04-07_hell_looms_print.html

Description: This article discusses the impacts of global warming on a global scale and on Manhattan. The article mentions that longer, hotter summers; droughts and less water in NYC reservoirs; rising sea levels; shorter winters; and stronger rains causing flooding are potential consequences of global warming in Manhattan and the Northeast.

\section{"Britain Drafts Laws to Slash Carbon Emissions"}

Type: Press article

By: New York Times - Cowell, A.

Published: March 14, 2007

Link: http://www.nytimes.com/2007/03/14/world/europe/14britain.html? rr=1\&oref=slogin\&pagewanted=print

Description: Britain proposing laws to slash carbon emissions

“A Glacial Pace on Warming”

Type: Website - Wallstreetandtech.com

By: Editor

Published: 2007

Link: http://www.wallstreetandtech.com/showArticle.jhtml?articleID=199202353

Description: Describes the concerns with the NYC energy grid's ability to keep up with growing energy demands. The article also mentions Con Edison's investments in the electric system to handle growing demand. 
“Top Scientists Warn of Water Shortages and Disease Linked to Global Warming”

Type: Press article

By: New York Times

Published: March 11, 2007

Link: http://www.nytimes.com/2007/03/12/science/earth/12climate.html? r=1\&pagewanted=print\&oref=slogin

Description: Discusses the information about global warming's impacts that will likely be stated at a meeting in Belgium in April by top scientists. It also mentions the information about global warming's impacts in report by the Intergovernmental Panel on Climate Change. Specifically, the scientists and report mentions, the flooding of homes dues to rising temperatures and seas levels, the destruction of polar beard habitats, starvation in parts of the world, change in species' habits and natural habitats, and water shortages (especially in Africa and Latin America).

"The Real Riddle of Changing Weather: How Safe is My Home?"

Type: Press article

By: New York Times - Rogers, T. K.

Published: March 11, 2007

Link: http://www.nytimes.com/2007/03/11/realestate/11cov.html?ref=realestate\&pagewanted=print

Description: This article discusses the potential impacts of global warming (flooding, sea level rise, more intense storms) on NYC property. The article also mentions the NYC Plan 2030 initiatives, and the framework for a plan (to be announced by Mayor Bloomberg in early April). The article brings to light that some insurers are refusing to renew homeowner's insurance policies in eight counties downstate which includes NYC. The article points out that flooding and the increased frequency of northeasters in the area could disrupt the power infrastructure by making power lines inoperable. Stuart Gaffin of the Columbia's Climate Research Center also comments in the article.

\section{"In a Test of Capturing Carbon Dioxide, Perhaps a Way to Temper Global Warming"}

Type: Press article

By: - New York Times - Wald, M. L.

Published: March 14, 2007

Link: http://www.nytimes.com/2007/03/15/business/15carbon.html?pagewanted=print

Description: Discusses the largest testing of carbon sequestration technology by American Electric Power.

\section{Other Sources}

\section{“NYCDEP \& Climate Change / NYCDEP Water Demand and Wastewater Flow Projections"}

Type: Report

By: NYC Department of Environmental Protection

Published: 2005

Link: http://home2.nyc.gov/html/dep/html/news/dwconf.html

Description: A presentation discussing the impacts of climate change on water and wastewater systems, NYC DEP's activities to address the climate change in the water and wastewater systems, and NYC DEP water demand and wastewater flow projections.

"Vulnerability of the New York City metropolitan area to coastal hazards, including sea level rise: Inferences for urban coastal risk management and adaptation policies. Managing Coastal Vulnerability”

Type: Report - Elsevier: 141-158.

By: Jacob, K., Gornitz, V., Rosenzweig, C.

Published: 2007

Link: http://pubs.giss.nasa.gov/authors/crosenzweig.html 
Description: "Many of the world's largest cities are situated at coasts and in estuaries at or near sea level. Major coastal urban centers have long been vulnerable to natural hazards, such as storm surges, shoreline erosion, or even the occasional destructive tsunami. By the end of this century, increased rates of sea-level rise (SLR) could cause permanent inundation of portions of low-lying coastal cities, repeated flooding episodes, and more severe beach erosion. The anticipated SLR will challenge coastal managers and decision makers to adapt to and mitigate these potentially adverse effects of climate warming in innovative and creative ways.”

\author{
"Assessing potential public health impacts of changing climate and land uses: The New York Climate and Health \\ Project” \\ Type: Report -Report - In Regional Climate Change and Variability. K. D. M. Ruth, P. Kirshen. Cheltenham, U.K, \\ New Horizons in Regional Science. \\ By: Kinney, P., Rosenthal, J., Rosenzweig, C., Hogrefe, C., Solecki, W., Knowlton, K., Small, C., Lynn, B., \\ Civerolo, K., Ku, J., Goldberg, R., Oliveri, C. \\ Published: 2006. \\ Link: http://pubs.giss.nasa.gov/authors/crosenzweig.html
}

Description: "Over the next 50 years, a rapidly urbanizing world population will confront significant environmental change caused by a warming climate and rapid conversion of land. The Intergovernmental Panel on Climate Change (IPCC) Third Assessment protects that global averaged surface temperature will increase by $1.4-5.8^{\circ} \mathrm{C}\left(2.4-10.4^{\circ} \mathrm{F}\right)$ by 2100. Simultaneously, human populations are carrying out a rapid and substantial conversion of land from natural to human dominated uses. To be responsible stewards of both human health and biological diversity in the coming century, societies will need to develop and institutionalize better models describing and predicting the interactions between these global drivers and the health of the planet. The objective of the project described here is to begin to build and apply a modeling framework that assesses potential future public health impacts of both climate change and land use change in the New York metropolitan region."

\author{
“Green Roofs in the New York Metropolitan Region: Research Report” \\ for Space Studies. \\ Type: Report, By: Rosenzweig, C., Gaffin, S., Parshall, L. \\ Published: 2006 \\ Link: http://pubs.giss.nasa.gov/docs/2006/2006_Rosenzweig_etal.pdf
}

Type: Report - New York, Columbia University Center for Climate Systems Research and NASA Goddard Institute

Description: "New York City faces a suite of extant and emergent environmental and human health challenges in the 21st century. The need to understand the nature of these challenges, and to evaluate potential mitigation and adaptation strategies, requires innovative scientific research and assessment, coupled with sound policy development, land-use planning, technological innovation, and urban development. This study explores the development of "green" or vegetated rooftops in New York City - a technology that has been implemented in municipalities around the world as a strategy for mitigating such challenges as storm water runoff pollution and high urban temperatures."

\title{
ENERGY
}

\section{$\underline{\text { Press Articles }}$}

"Power Line Pits City's Energy Needs Against Upstate Opposition"

Type: Press article

By: Associated Press - New York Sun. Published: March 5, 2007 (AP); March 9, 2007 (The New York Sun),

Link: http://www.nysun.com/article/49812?page_no=1 
Description: This article describes the need for more and cheaper power for NYC and the resistance it faces from upstate communities.

\author{
“The NYISO Issues Second Reliability Needs Assessment” \\ Type: Press article \\ By: Businesswire \\ Published: 2007 \\ Link: http://biz.yahoo.com/bw/070319/20070319006039.html?.v=1\&printer=1
}

Description: The New York Independent System Operator Board of Directors approved New York state's second Reliability Needs Assessment. This assessment states the bulk electricity grid needs for New York State from 20072016. The assessment reveals that by 2011, additional power will be needed to meet demands in the southeast region of New York State. By 2016 this problem will be more critical if not resolved. The article mentions a growth in electricity demand in the Lower Hudson Valley and New York City as creating the need for power by 2011. NYISO also forecasted the retirement of the Charles Poletti Plant in 2009 and several other plants between 2007 and 2009. The generating capacity of the plants forecasted to retire is 1675 MW. NYISO anticipates the addition of 1204 MW during 2007-2009.

\title{
“Don't Panic, But the Grid's Going Down”
}

Type: Website

By: Crosman, P.

Published: 2007

Link:

http://www.wallstreetandtech.com/printableArticle.jhtml;jsessionid=ARMCPEKUXUBJ0QSNDLPSKH0CJUNN2J $\underline{\text { VN?articleID }=199202353}$

Description: Describes the concerns with the NYC energy grid's ability to keep up with growing energy demands. The article also mentions Con Edison's investments in the electric system to handle growing demand.

\section{"Saving on Utilities Just Takes Gazing into a Crystal Ball"}

Type: Press article

By: USA Today - Davidson, P.

Published: March 21, 2007

Link: http://www.usatoday.com/money/industries/energy/2007-03-20-smart-meter-main-usat_N.htm

Description: This article discusses new strategies for energy conservation that involve using electricity at different times of the day to save money and energy. The use of smart metering is described as a tool for energy conservation and time-of-use pricing.

\section{"A U.S. Alliance to Update the Light Bulb"}

Type: Press article By: New York Times - Wald, M. L.

Published: March 14, 2007

Link: http://www.nytimes.com/2007/03/14/business/14light.html?ref=business\&pagewanted=print Description: Discusses a movement to ban or update the incandescent light bulb. 


\section{“Columbia Joins Energy Conservation Program”}

Type: Press article

By: New York Business - Marshall, S.

Published: February 22, 2007

Link: http://www.newyorkbusiness.com/apps/pbcs.dll/article?AID=/20070222/FREE/70222008/1046/breaking

Description: "Columbia University has signed on to an energy reduction incentive program called "Operation Save New York. The conservation program, operated by Energy Curtailment Specialists, Inc. in Buffalo, will pay the university for saving electricity in certain areas of its operations. Columbia will receive day-ahead notice of periods when the electric grid is forecast to be unstable, and will respond by turning off lighting, elevators and non-critical equipment. Without this kind of program, the typical way of dealing with imbalances on the electric grid is to enact rolling brownouts that leave communities in the dark without any warning. New York State's electric supply is static, but demand is increasing every year. Programs like "Operation Save" could potentially lower demand by 3\%."

\section{Other Sources}

\section{“Commercial Buildings Energy Consumption Survey (CBECS)”}

Type: Report

By: US Department of Energy-Energy Information Administration.

Published: 2003

Link: http://www.eia.doe.gov/emeu/cbecs/cbecs2003/public_use_2003/cbecs_pudata2003.html

Description: Database for energy use in buildings by census region.

\section{“Annual Energy Outlook 2005”}

Type: Report

By: US Department of Energy-Energy Information Administration. Washington, D.C.,

Published: 2005

Link: http://www.eia.doe.gov/oiaf/aeo/index.html

Description: EIA's annual energy forecast report

“Annual Energy Review 2004”, Washington, D.C.

Type: Report

By: US Department of Energy - Energy Information Administration

Published: 2005

Link: www.eia.doe.gov/emeu/aer/pdf/aer.pdf

Description: EIA's annual energy report

\section{“The Path to Perfect Power, Galvin Electricity Initiative”}

Type: Report

By: Galvin Power

Published: 2007

Link: http://www.galvinpower.org/files/Complete_NewTechnologies_Rpt.pdf

Description: Discusses the new technologies that will allow energy consumers to control on how they utilize electricity. 
"Technology Set to Revolutionize Energy Use, Changes Forecast for Industry"

Type: Report

By: Galvin Power in Transmission and Distribution World

Published: 2007

Link: http://tdworld.com/news/galvin-electricity-control-report/

Description: This article summarizes a report that discusses future home energy management devices. These new technologies will require utilities to make changes to the energy infrastructure, and the devices will save customers money.

\section{"Mirant Power Plant in Stony Point Could Shut Down Tomorrow"}

Type: Press article

By: Incalcaterra, L.

Published: 2007

Link:

http://www.thejournalnews.com/apps/pbcs.dll/article?AID=/20070429/NEWS03/704290398\&template=printart

Description: The article states that the Mirant Power Plant in Stony Point might shut down because it failed to update pollution control upgrades. The article discusses the impacts on tax revenues to the local area, but it does not describe the impacts to the energy system.

\section{"Power Deficit Expected for Lower NY by 2011"}

Type: Press article

By: Times Herald-Record - Levensohn, M.

Published: March 20, 2007

Link: http://www.recordonline.com/apps/pbcs.dll/article?AID=/20070320/BIZ/703200311/-

$\underline{1 / \text { BIZ\&template=printart }}$

Description: Discusses the information in the NYISO report.

\section{“Home Energy Briefs, \#6 Cleaning Appliances”}

Type: Report

By: Rocky Mountain Institute

Published: 2004

Link: http://www.rmi.org/images/other/Energy/E04-16_HEB6CleaningApps.pdf

Description: Information on energy use by household cleaning appliances.

\section{ENERGY-WATER NEXUS}

\section{Other sources}

\section{"Energy-Water Nexus brochure"}

Type: Brochure

By: DOE Interlaboratory EWN Team

Published: 2005

Link: http://www.sandia.gov/energy-water/docs/NEXUS_v4.pdf

Description: This brochure gives an overview of the energy-water connection, national concerns and needs. 
“Electric Power Research Institute Water \& Sustainability (Volume 3): U.S. Water Consumption for Power Production-The Next Half Century"

Type: Report

By: EPRI

Published: 2002

Link: http://www.epriweb.com/public/000000000001006786.pdf

Description: This report discusses the water consumption for energy production by power plant type and estimates of future energy production and water consumption.

\section{"Statistical Programs of the United States Government FY 2007"}

Type: Report

By: Office of Management and Budget (United States)

Published: 2006

Link: http://www.whitehouse.gov/OMB/inforeg/07statprog.pdf

Description: The Statistical Programs of the United States Government FY 2007 report describes EIA data and statistics that will not be collected.

"Methodology for Analysis of the Energy Intensity of California's Water Systems, and an Assessment of Multiple Potential Benefits through Integrated Water-Energy Efficiency Measures”

Type: Report

By: Wilkinson, R.

Published: 2000

Link: http://www.es.ucsb.edu/faculty/Wilkinson_EWRPT01\%20DOC.pdf

Description: Discusses the energy intensity of the California water system.

\section{NEW YORK CITY BACKGROUND}

\section{$\underline{\text { Press Articles }}$}

“City Weighing Plans to Reduce Air Pollution”

Type: Press article

By: Fredrickson, T.

Published: 2007

Link: http://www.newyorkbusiness.com/apps/pbcs.dll/article?AID=200770323008

Description: This article discusses the Mayor Bloomberg's plan to lower air pollution. The strategies include requiring improvements to energy efficiency prior to selling property and encouraging the construction of newer power plants.

"City to Seek Broader Power Over Buildings"

Type: Press Article

By: New York Times - Scott, J.

Published: April 12, 2007

Link:

http://www.nytimes.com/2007/04/12/nyregion/12housing.html?ei=5070\&en=2c66936e308ad033\&ex=1177041600 \&emc=eta1\&pagewanted=print 
Description: Article discusses a proposed bill that will allow the Department of Housing Preservation and Development to bring run down, poorly maintained buildings up to code. Building owners would be required to pay for the improvements. This measure would provide more suitable and energy-efficient housing in the city over the next five years.

\section{Other Sources}

“GreenNYC - Water Quality”

Type: Report/Website

By: NYC

Published: 2006

Link: http://www.nyc.gov/html/planyc2030/downloads/pdf/greenyc_water-quality.pdf

Description: Specific energy-water related concerns for New York City are shown in the links to the presentation on water quality. These issues are central to the energy-water nexus.

\section{“MaintainNYC - ENERGY”}

Type: Report/Website

By: NYC

Published: 2006

Link: http://www.nyc.gov/html/planyc2030/downloads/pdf/maintainyc energy.pdf

Description: Specific energy-water related concerns for New York City are shown in the link to the presentation on energy. These issues are central to the energy-water nexus.

\section{“MaintainNYC - Water Network"}

Type: Report/Website

By: NYC

Published: 2006

Link: http://www.nyc.gov/html/planyc2030/downloads/pdf/maintainyc_water-network.pdf

Description: Specific energy-water related concerns for New York City are shown in the links to the presentation on the water network. These issues are central to the energy-water nexus.

\section{“PlaNYC2030"}

Type: Report/Website

By: NYC

Published: 2006

Link: http://www.nyc.gov/html/planyc2030/html/home/home.shtml

Description: Discusses the Plan NYC 2030 initiative introduced by Mayor Bloomberg in December 2006. Summaries of the key issues and ideas are on the main page.

\section{"Sustainability Challenges and Goals for New York City Through 2030"}

Type: Speech

By: Mayor Michael Bloomberg

Published: 2006

Link:

http://www.nyc.gov/portal/site/nycgov/menuitem.c0935b9a57bb4ef3daf2f1c701c789a0/index.jsp?pageID=mayor_p ress_release\&catID=1194\&doc_name=http\%3A\%2F\%2Fwww.nyc.gov\%2Fhtml\%2Fom\%2Fhtml\%2F2006b\%2Fpr 432-06.html\&cc $=$ unused1978\&rc=1194\&ndi $=1$ 
Description: On Tuesday, December 12, 2006, at an event hosted by the League of Conservation Voters at the Queens Museum of Art, Mayor Michael R. Bloomberg delivered a major speech outlining sustainability challenges and goals for the City of New York through the year 2030.

\section{WATER AND WASTEWATER}

\section{Press Articles}

"Apple Water Threat"

Type: Press article

By: New York Post - Campanile, C.

Published: April 9, 2007

Link:

http://www.nypost.com/php/pfriendly/print.php?url=http://www.nypost.com/seven/04092007/news/regionalnews/ap ple_water_threat_regionalnews_carl_campanile.htm

Description: This article discusses the concerns about potential construction projects and development in upstate NY near the NYC drinking water supply reservoirs. It states that urban development could potentially affect water quality in the reservoirs and require NYC to build an $\$ 8$ billion filtration plant to treat Catskill-Delaware Reservoir water, which could lead to a 50 percent increase in water bills.

"Gotham's Water Woes"

Type: Press article

By: New York Post - Campanile, C.

Published: April 10, 2007

Link:

http://www.nypost.com/php/pfriendly/print.php?url=http://www.nypost.com/seven/04102007/postopinion/editorials/ gothams_water_woes_editorials_.htm

Description: This article discusses the concerns about potential construction projects and development in upstate NY near the NYC drinking water supply reservoirs. It states that urban development could potentially affect water quality in the reservoirs and require NYC to build an $\$ 8$ billion filtration plant to treat Catskill-Delaware Reservoir water, which could lead to a 50 percent increase in water bills.

\section{"New York City Ducks \$8B Soaking"}

Type: Press article

By: New York Post - Campanile, C.

Published: April 13, 2007

Link:

http://www.nypost.com/php/pfriendly/print.php?url=http://www.nypost.com/seven/04132007/news/regionalnews/ny c_ducks_8b_soaking_regionalnews_carl_campanile.htm

Description: This article states that the EPA decided that the NYC DEP will not have to build an $\$ 8$ billion filtration plant to treat water. The EPA ruled that DEP should spend \$300 million over the next ten years to purchase land in the water supply watershed areas to prevent development in these areas that could negatively impact water quality

\section{"New York City Water Rates Expected to Rise 11.5 Percent"}

Type: Press article

By: NY Times - DePalma, A.

Published: April 12, 2007 
Link:

http://www.nytimes.com/2007/04/11/nyregion/11water.html?ei=5070\&en=1a51debb4c9aae85\&ex=1177041600\&e mc=eta1\&pagewanted=print

Description: There is a proposed $11.5 \%$ increase in water rates for New York City. The NYC Water Board is expected to approve this increase and the new rates will take effect in July.

\section{"A Plan to Protect New York Water"}

Type: Press article

By: New York Times

Published: February 25, 2007

Link: http://www.nytimes.com/2007/02/25/opinion/nyregionopinions/NYCwater.html?_r=1\&oref=slogin

Description: It is about the single gravest threat to water quality in NYC -- development around the watersheds. Development around the watersheds could cause filtration requirements to increase to protect the water supply. More filtration plants means more electric demand which means more expensive water and electricity.

\section{"More Masses Huddling, but They Use Less Water"}

Type: Press article

By: New York Times - Roberts, S.

Published: October 3, 2006

Link:

http://www.nytimes.com/2006/10/03/nyregion/03water.html?ex=1317528000\&en=3ddc020626dad9b9\&ei=5090\&p $\underline{\text { artner}=\text { rssuserland\&emc }=r s s}$

Description: This article discusses water use in New York City.

\section{"Future Cloudy for \$1B Water Plant"}

Type: Press article

By: New York Post - Seifman, D.

Published: April 15, 2007

Link:

http://www.nypost.com/php/pfriendly/print.php?url=http://www.nypost.com/seven/04152007/news/regionalnews/fu ture_cloudy_for_1b_water_plant_regionalnews_david_seifman_city_hall_bureau_chief.htm

Description: The article states that the lowest bidder for the water filtration plant has pulled the bid, and the only other bidder is deciding whether to take the project. If the remaining bidder takes on the project, it will amount to an $18 \%$ increase in project price. New bids will have to be solicited if both bidders decide not to take on the project, which could increase the project cost since construction costs are increasing.

\section{Other Sources}

\section{"The Benefits of CSO Controls-NYC adopts nine minimum controls."}

Type: Report

By: Brosnan, T. M. and P. C.Heckler in Water Environment and Technology.

Published: 1996

Description: Papers on water and wastewater topics such as wet weather flows, combined sewer overflows, and industrial pre-treatment. 
“Development of a Wet Weather Operations Manual, A case Study”

Type: Report

By: Fangmann, S. and P. Heckler (2004)

Published: 2004 NYWEA 76th annual conference, New York.

Description: Papers on water and wastewater topics such as wet weather flows, combined sewer overflows, and industrial pre-treatment.

“Freshwater Supply: States' Views of How Federal Agencies Could Help Them Meet the Challenges of Expected Shortages"

Type: Report

By: U.S. General Accounting Office (GAO), Washington, D.C.

Published: 2003

Description: Discusses the results of a survey on water supplies in the U.S. Findings include potential water shortages and solutions for the water supply issues.

“NYC's Industrial Pre-Treatment Program-A Citizen/Government Success Story”

Type: Report

By: Heckler, P. and M. Londner, New York, NYCDEP.

Published: 1998

Description: Papers on water and wastewater topics such as wet weather flows, combined sewer overflows, and industrial pre-treatment.

“The State of the City's Waters 1994: The New York Harbor Estuary”

Type: Report

By: NYC Department of Environmental Protection - New York State Water Resources Institute Center for the Environment, Ithaca, NY

Published: 2000

Link: www.epa.gov/owm/wquality/chap06.pdf

Description: Discusses NYC Harbor estuary water quality.

“UN World Water Development Report 2: Water A Shared Responsibility”

Type: Report

By: UNESCO and Berghahn Books.

Published: 2006

Link: http://www.unesco.org/water/wwap/wwdr2/table_contents.shtml

Description: Discusses issues and concerns with water resources throughout the world.

"California Desalination Report with More Than a Grain of Subjectivity"

Type: Report

By: Voutchkov, N. in Water Conditioning and Purification.

Published: 2007

Link: http://www.wcponline.com/PDF/0701Voutchkov.pdf

Description: Article on costs and benefits of the California Desalination Initiative. The article was written to refute a Pacific Institute Study which states that California is over emphasizing desalination and not putting enough emphasis on reuse, reclamation and efficiency. 


\section{APPENDIX B}

\section{ACRONYMS \& GLOSSARY}




\section{ACRONYMS}

\begin{tabular}{|c|c|}
\hline ADG & Anaerobic Digester Gas \\
\hline AP & Associated Press \\
\hline ARP & Ammonia Recovery Process \\
\hline ASE & Alliance to Save Energy \\
\hline AWWARF & American Water Works Association Research Foundation \\
\hline BGD & Billion gallons per day \\
\hline BOD & Biological oxygen demand \\
\hline BNL & Brookhaven National Laboratory \\
\hline BNR & Biological nutrient removal \\
\hline City & New York City \\
\hline CEC & California Energy Commission \\
\hline DEP & Department of Environmental Protection \\
\hline DOE & Department of Energy \\
\hline FAD & Filtration Avoidance Determination \\
\hline EDC & Economic Development Corporation \\
\hline EEEAG & Energy, Environment and Economic Analysis Group \\
\hline EERE & Energy Efficiency and Renewable Energy \\
\hline EPA & Environmental Protection Agency \\
\hline EPRI & Electric Power Research Institute \\
\hline EWN & Energy-Water Nexus \\
\hline GPRA & Government Performance Results Act \\
\hline kWh & kilowatt hours \\
\hline MARKAL & MARKet ALlocation \\
\hline MG & million gallons \\
\hline MGD & million gallons per day \\
\hline MW & megawatts \\
\hline PlaNYC2030 & Plan New York City 2030 initiative \\
\hline $\mathrm{NE}$ & Nuclear Energy \\
\hline NETL & National Energy Technology Laboratory \\
\hline NY & New York \\
\hline NYC & New York City \\
\hline NYCDCP & New York City Department of City Planning \\
\hline NYCDEP & New York City Department of Environmental Protection \\
\hline NYC MARKAL & New York City MARKAL model \\
\hline NYISO & New York Independent System Operator \\
\hline NYPA & New York Power Authority \\
\hline NYSDEC & New York State Department of Environmental Conservation \\
\hline OMB & Office of Management and Budget (United States) \\
\hline SHARON & Single reactor system for High activity Ammonia Removal Over Nitrate \\
\hline UN & United Nations \\
\hline US & United States \\
\hline US EPA & United States Environmental Protection Agency \\
\hline UV & ultraviolet \\
\hline WWTP & Wastewater treatment plant \\
\hline
\end{tabular}




\section{APPENDIX C \\ NEW YORK CITY: SUPPLEMENTAL WATER AND ENERGY INFORMATION}


New York City Water Supply System (Source: NYC DEP http://www.nyc.gov/html/dep/)

- 1.1-1.3 BGD supplied

- 19 reservoirs, 3 controlled lakes

- 3 aqueducts

- 2 distribution reservoirs

- 3 rock tunnels in the city $(1,2,3)$

- Network of risers and 6000 miles of distribution mains

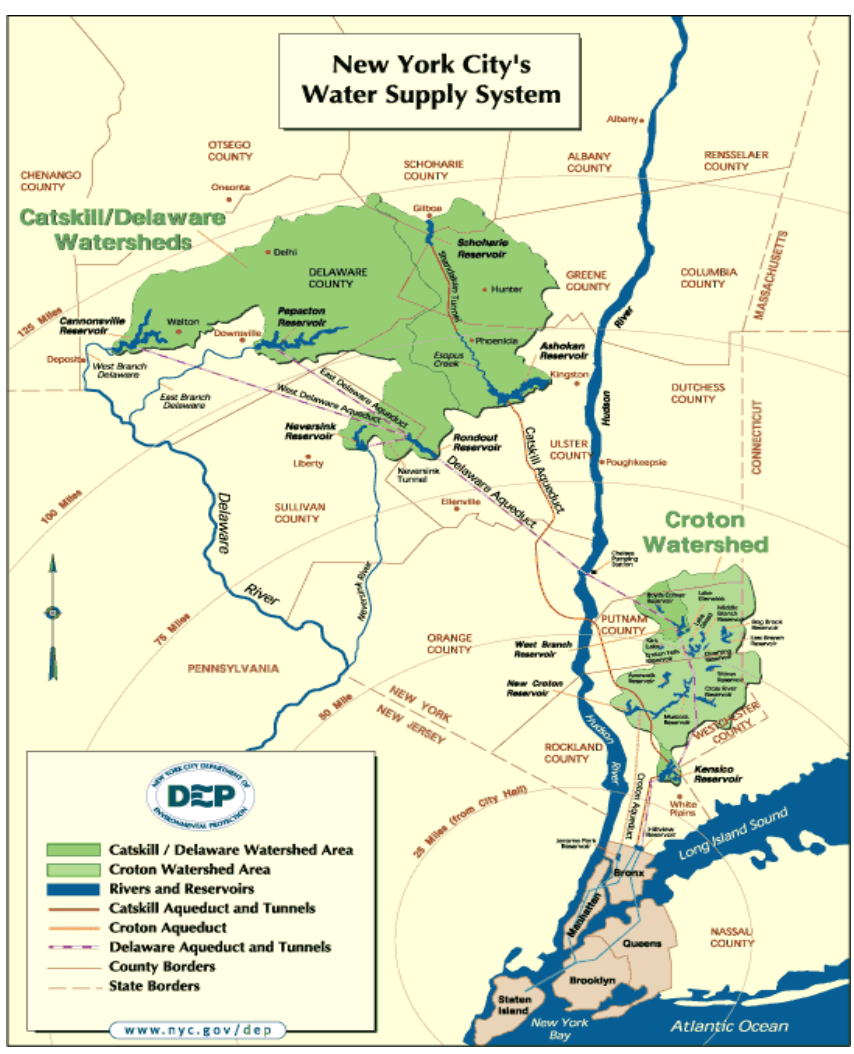

\section{New York City Wastewater Treatment System (Source: NYC DEP} http://www.nyc.gov/html/dep/)

- $\quad 1.4$ BGD treated

- 14 wastewater pollution control plants

- 93 pumping stations

- 494 permitted outfalls

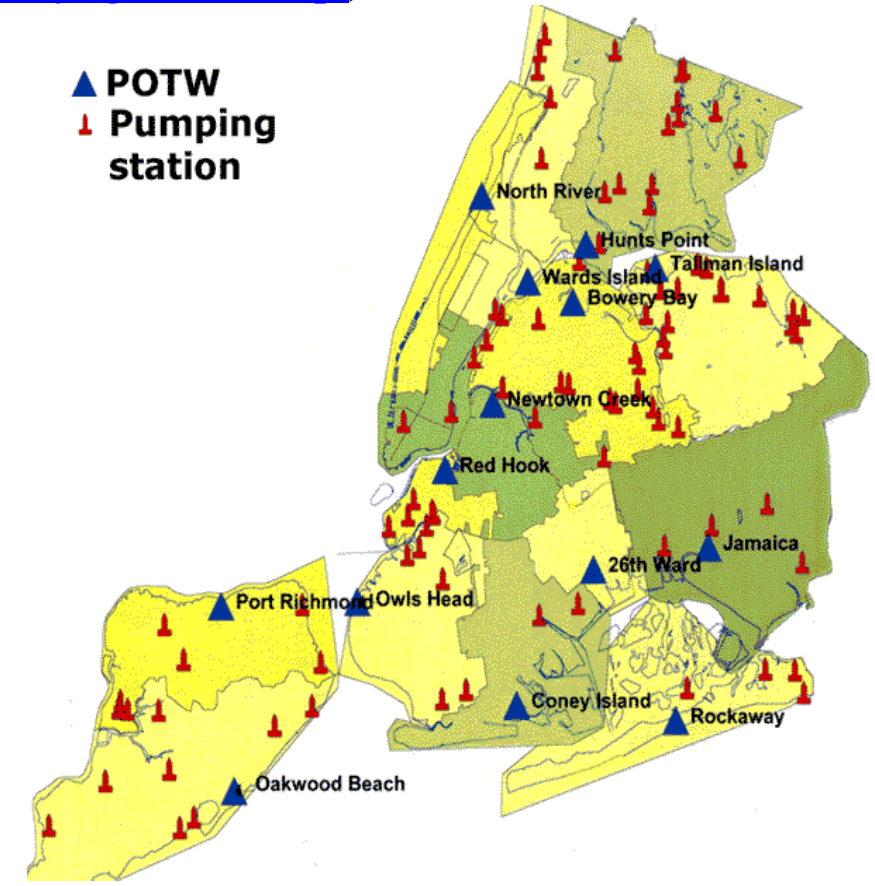




\section{NYC Energy Suppliers}

- New York Power Authority

- NRG Energy

- Reliant Resources

- Keyspan Energy

- Palmark, Inc.

- El Paso Merchant Energy

- Con Edison, Inc.

\section{NYC Power Plants}

- $74^{\text {th }}$ Street plant- operated by Con Edison, Inc.

- Warbasse Cogen plant —operated by El Paso Merchant Energy

- Hudson Avenue plant- operated by Con Edison, Inc.

- Kennedy International plant- operated by Calpine

- Waterside plant- operated by Con Edison, Inc.

- Brooklyn Navy Yard- operated by Palmark, Inc.

- Narrows Generating station- operated by Reliant Resources

- East River plant- operated by Con Edison, Inc.

- Gowanus Gas Turbines station-operated by Reliant Resources

- Astoria Gas Turbines- operated by NRG Energy

- Charles Poletti plant- operated by Power Authority of State of NY (NYPA)

- Arthur Kill Generation station- operated by NRG Energy

- Astoria Generating Station- operated by Reliant Resources

- Ravenswood plant- operated by Keyspan Energy

- Several other smaller power plants operated by various entities

NYC Energy Delivery and Transmission

- Consolidated Edison, Inc.-Electric, Steam, and Gas

- Keyspan Energy, Corporation-Electric and Gas 


\section{APPENDIX D}

\section{DATA FOR NYC WATER-MARKAL MODELING SCENARIOS}




\begin{tabular}{|c|c|c|c|}
\hline $\begin{array}{l}\text { Inputs to NYC } \\
\text { MARKAL Model }\end{array}$ & $\begin{array}{l}\text { MARKAL DATA } \\
\text { Fresh Water System }\end{array}$ & Metric & $\begin{array}{l}\text { Years of } \\
\text { Data }\end{array}$ \\
\hline Water Quantity & $\begin{array}{l}\text { - } \\
\text { - } \quad \text { Start date and lifetime of Catskill/Delaware system } \\
\text { - } \quad \text { Yearly quantity of water supplied from Catskill/Delaware } \\
\text { - } \quad \text { Yearly quantity of water supplied from Croton system } \\
\text { - } \quad \text { Yearly quantity of water demanded by commercial, industrial, } \\
\text { and residential sectors (individually) }\end{array}$ & $\mathrm{MG} / \mathrm{yr}$ & $\begin{array}{l}\text { 2005, 2010, } \\
2015,2020 \\
2025,2030\end{array}$ \\
\hline $\begin{array}{l}\text { Technology } \\
\text { Characteristics }\end{array}$ & $\begin{array}{l}\text { - Technical efficiency and yearly operating availability of } \\
\text { - Catskill/Delaware system } \\
\text { Technical efficiency and yearly operating availability of } \\
\text { Croton system }\end{array}$ & $\begin{array}{l}1=100 \% \\
\text { Expressed in } \\
\text { decimal fraction }\end{array}$ & \\
\hline $\begin{array}{l}\text { Operation and } \\
\text { Maintenance Costs }\end{array}$ & $\begin{array}{l}\text { - Yearly operation and maintenance costs for the } \\
\text { Catskill/Delaware system (includes labor, equipment, } \\
\text { treatment costs, disposal, conveyance. etc.) } \\
\text { (Include with and without the UV treatment system) } \\
\text { Yearly operation and maintenance costs for the Croton system } \\
\text { (includes labor, equipment, treatment costs, disposal, } \\
\text { conveyance, etc.) } \\
\text { (Include with and without the filtration treatment system) }\end{array}$ & $\begin{array}{l}\text { US dollars } \\
(2000)\end{array}$ & \\
\hline Investment Costs & $\begin{array}{l}\text { Investment costs and year of investment for the } \\
\text { Catskill/Delaware system } \\
\text { (Include with and without the UV treatment system) } \\
\text { Investment costs and year of investment for the Croton system } \\
\text { (Include with and without the filtration treatment system) }\end{array}$ & $\begin{array}{l}\text { US dollars } \\
\text { (2000) and year } \\
\text { of investment }\end{array}$ & \\
\hline Energy Use & $\begin{array}{l}\text { - Yearly energy use and cost for Delaware System for all energy } \\
\text { carriers (electricity, natural gas) }\end{array}$ & $\begin{array}{l}\text { Natural Gas } \\
\text { (Therms) }\end{array}$ & \\
\hline Energy Cost & $\begin{array}{l}\text { Yearly energy use and cost for the Croton System for all } \\
\text { energy carriers (electricity, natural gas) }\end{array}$ & $\begin{array}{l}\text { Electricity } \\
\text { (MWhr) }\end{array}$ & \\
\hline Emissions & Air and water & Tons & \\
\hline
\end{tabular}




\begin{tabular}{|c|c|c|c|}
\hline $\begin{array}{l}\text { Inputs to NYC } \\
\text { MARKAL Model }\end{array}$ & $\begin{array}{c}\text { MARKAL DATA } \\
\text { Wastewater System }\end{array}$ & Metric & $\begin{array}{c}\text { Years of } \\
\text { Data }\end{array}$ \\
\hline $\begin{array}{l}\text { Technology } \\
\text { Characteristics }\end{array}$ & $\begin{array}{l}\text { - } \\
\text { - } \\
\text { - } \\
\text { production) } \\
\text { - }\end{array}$ & $\begin{array}{l}1=100 \% \\
\text { Expressed in } \\
\text { decimal } \\
\text { fraction }\end{array}$ & $\begin{array}{l}2005,2010 \\
2015,2020 \\
2025,2030\end{array}$ \\
\hline $\begin{array}{l}\text { Wastewater } \\
\text { Quantity }\end{array}$ & $\begin{array}{ll}\text { - } & \text { Investment costs and year of investment for WWTP } 1 \\
\text { - } & \text { Investment costs and year of investment for WWTP } 2 \\
\text { - } & \text { Investment costs and year of investment for WWTP } 3\end{array}$ & $\begin{array}{l}\text { US dollars } \\
(2000) \text { and } \\
\text { year of } \\
\text { investment }\end{array}$ & \\
\hline $\begin{array}{l}\text { Operation and } \\
\text { Maintenance } \\
\text { Costs }\end{array}$ & $\begin{array}{l}\text { - Yearly quantity of water treated by WWTP } 1 \text { (no energy } \\
\text { production) } \\
\text { Yearly quantity of water treated by WWTP } 2 \text { (energy } \\
\text { production) } \\
\text { Yearly quantity of water treated by WWTP } 3 \text { (with odor } \\
\text { control) } \\
\text { Yearly quantity of water treated from the commercial, } \\
\text { industrial, and residential sectors (individually) }\end{array}$ & MG/yr & \\
\hline $\begin{array}{l}\text { Energy Use and } \\
\text { Costs for } \\
\text { Collection, } \\
\text { Treatment, and } \\
\text { Conveyance }\end{array}$ & $\begin{array}{l}\text { Yearly operation and maintenance costs for WWTP } 1 \\
\text { (includes labor, equipment, disposal, treatment, and } \\
\text { disposal, conveyance, etc.) } \\
\text { Yearly operation and maintenance costs for WWTP } 2 \\
\text { (includes labor, equipment, treatment, and disposal, } \\
\text { conveyance, etc.) } \\
\text { - Yearly operation and maintenance costs for WWTP } 3 \\
\text { (includes labor, equipment, treatment, disposal, } \\
\text { conveyance, etc.) }\end{array}$ & $\begin{array}{l}\text { US dollars } \\
\text { (2000) }\end{array}$ & \\
\hline $\begin{array}{l}\text { Energy } \\
\text { Production; }\end{array}$ & $\begin{array}{ll}\text { - } & \text { Yearly energy use for WWTP } 1 \text { for all energy carriers } \\
\text { (electricity, natural gas, etc.) } \\
\text { - } & \text { Yearly energy use for WWTP } 2 \text { for all energy carriers } \\
\text { (electricity, natural gas, etc.) } \\
\text { - } & \text { Energy production by WWTP } 2 \\
\text { - } & \text { Emissions from WWTP } 1 \\
\text { - } & \text { Emissions from WWTP } 2 \\
\text { - } & \text { Emissions from WWTP } 3\end{array}$ & $\begin{array}{l}\text { Electricity } \\
\text { (MWhr) } \\
\text { Natural Gas } \\
\text { (Therms) } \\
\text { Tons }\end{array}$ & \\
\hline
\end{tabular}




\begin{tabular}{|c|c|c|c|}
\hline $\begin{array}{c}\text { Inputs to NYC } \\
\text { MARKAL Model }\end{array}$ & $\begin{array}{l}\text { MARKAL DATA } \\
\text { Water Conservation }\end{array}$ & Metric & $\begin{array}{c}\text { Years of } \\
\text { Data }\end{array}$ \\
\hline $\begin{array}{l}\text { Technology } \\
\text { Information }\end{array}$ & $\begin{array}{l}\text { - Start date and lifetime of typical EnergyStar front load } \\
\text { washer } \\
\text { - Start date and lifetime of typical EnergyStar top load } \\
\text { washer }\end{array}$ & Years & $\begin{array}{l}\text { 2005, 2010, } \\
2015,2020, \\
2025,2030\end{array}$ \\
\hline & $\begin{array}{l}\text { - } \quad \text { Technical efficiency and yearly operating availability of } \\
\text { typical EnergyStar front load washer } \\
\text { - } \quad \text { Technical efficiency and yearly operating availability of } \\
\text { EnergyStar top load washer } \\
\text { - } \quad \text { Yearly quantity of water used for front load washing } \\
\text { - } \quad \text { Yearly quantity of water used for top load washing }\end{array}$ & $\begin{array}{l}1=100 \% \\
\text { Expressed in } \\
\text { decimal } \\
\text { fraction } \\
\text { MG/yr }\end{array}$ & \\
\hline \multirow{4}{*}{$\begin{array}{l}\text { NYC-Specific } \\
\text { Technology } \\
\text { Information }\end{array}$} & $\begin{array}{l}\text { Yearly operation and maintenance costs for front load } \\
\text { washer } \\
\text { - Yearly operation and maintenance costs for top load } \\
\text { washer }\end{array}$ & $\begin{array}{l}\text { US dollars } \\
(2000)\end{array}$ & \\
\hline & $\begin{array}{l}\text { Investment costs and year of investment for front load } \\
\text { washer } \\
\text { Investment costs and year of investment for top load } \\
\text { washer }\end{array}$ & $\begin{array}{l}\text { US dollars } \\
(2000) \text { and } \\
\text { year of } \\
\text { investment }\end{array}$ & \\
\hline & $\begin{array}{l}\text { Yearly energy use for front load washer (electricity, } \\
\text { natural gas) } \\
\text { Yearly energy use for top load washer (electricity, } \\
\text { natural gas) }\end{array}$ & $\begin{array}{l}\text { Electricity } \\
\text { (MW) } \\
\text { Natural Gas } \\
\text { (Therms) }\end{array}$ & \\
\hline & $\begin{array}{l}\text { - } \\
\text { - } \\
\text { - }\end{array}$ & & \\
\hline
\end{tabular}




\begin{tabular}{|c|c|c|c|}
\hline $\begin{array}{c}\text { Inputs to NYC } \\
\text { MARKAL Model }\end{array}$ & MARKAL DATA & Metric & $\begin{array}{l}\text { Years of } \\
\text { Data }\end{array}$ \\
\hline $\begin{array}{l}\text { Quantity of } \\
\text { treated water }\end{array}$ & $\begin{array}{l}\text { - Yearly quantity of water treated and used by truncated } \\
\text { combined cycle } \\
\text { - } \quad \text { Yearly quantity of water treated and used by closed loop }\end{array}$ & $\begin{array}{l}\text { Years } \\
\text { MG/yr }\end{array}$ & $\begin{array}{l}2005,2010 \\
2015,2020 \\
2025,2030\end{array}$ \\
\hline $\begin{array}{l}\text { Technology } \\
\text { Characteristics }\end{array}$ & $\begin{array}{l}\text { - Start date and lifetime of steam production-truncated } \\
\text { - } \quad \text { Sombined cycle system } \\
\text { - } \quad \text { Technical efficiency and yearly operating availability of } \\
\text { truncated combined cycle steam gen. } \\
\text { - Technical efficiency and yearly operating availability of } \\
\text { closed loop steam gen. }\end{array}$ & $\begin{array}{l}1=100 \% \\
\text { Expressed in } \\
\text { decimal } \\
\text { fraction }\end{array}$ & \\
\hline $\begin{array}{l}\text { Operation and } \\
\text { Maintenance } \\
\text { Costs }\end{array}$ & $\begin{array}{l}\text { Yearly operation and maintenance costs for truncated } \\
\text { combined cycle (includes labor, equipment, treatment, } \\
\text { disposal, etc.) } \\
\text { Yearly operation and maintenance costs for closed loop } \\
\text { (includes labor, equipment, treatment, disposal, etc.) }\end{array}$ & $\begin{array}{l}\text { US dollars } \\
\text { (2000) }\end{array}$ & \\
\hline Investment Costs & $\begin{array}{l}\text { - Investment costs and year of investment for truncated } \\
\text { combined cycle } \\
\text { Investment costs and year of investment for closed loop } \\
\text { - } \quad \begin{array}{l}\text { Yearly steam generated by truncated combined cycle } \\
\text { (and by season/peak/off-peak) } \\
\text { Yearly steam generated by closed loop (and by } \\
\text { season/peak/off-peak) }\end{array}\end{array}$ & 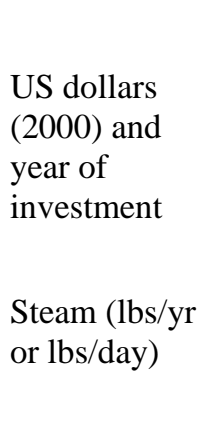 & \\
\hline Emissions & - $\quad$ Air and Water emissions & Tons & \\
\hline Climate & - $\quad$ Climate issues would link externally into MARKAL & & $\begin{array}{l}2005,2010, \\
2015,2020, \\
2025,2030\end{array}$ \\
\hline
\end{tabular}

